\title{
IMF Programmes, Fiscal Policy and Growth: Investigation of Macroeconomic Alternatives in an OLG Model of Growth for Turkey ${ }^{1}$
}

\author{
EBRU VOYVODA \& ERINÇ YELDAN \\ Bilkent University, Ankara, Turkey. E-mail: voyvoda@bilkent.edu.tr, yeldane@ \\ bilkent.edu.tr
}

\begin{abstract}
In this paper, we investigate the fiscal policy alternatives on domestic debt management and public expenditures on education, cohort welfare, and growth for the Turkish economy. We utilise a growth model in the overlapping generations (OLG) tradition with intertemporally optimising agents and open capital markets, calibrated to the Turkish economy in 1990s. We examine the macroeconomic effects of the current IMF-led austerity programme driven by the objective of attaining primary fiscal surpluses and illustrate the ruinous effects of constrained human capital investments due to insufficient funds to public education, and constrained real production activities due to the current mode of financing of domestic debt. We then examine various taxation alternatives to mitigate the reductions in the availability of public funds to reproducible factors of production. Our results suggest that the current fiscal programme based on the primary surplus objective suffers from serious trade-offs on growth and fiscal targets, and that an alternative public expenditures programme with the objective of reviving public funds for education and for social infrastructure is likely to produce superior economic performance.
\end{abstract}

Comparative Economic Studies (2005) 47, 41-79. doi:10.1057/palgrave.ces.8100065

Keywords: Turkey, fiscal policy, IMF austerity, OLG growth models

JEL Classifications: F02, F33, F40, E62

${ }^{1} \mathrm{~A}$ previous version of this paper was presented at the VIth METU International Conference on Economics, Ankara, September, 2002. We are grateful to Marcelle Mérette, Jordi Caballé, Oktar Türel, Erdem Başçi and Serdar Sayan for their advice and suggestions and to colleagues at Bilkent and participants of the above conference for their valuable suggestions and comments on earlier drafts of the paper. We have also benefited from discussions with Irma Adelman, Xinshen Diao, Terry Roe, Özlem Onaran and Refet Gürkaynak. All usual caveats, of course, do apply. 


\section{INTRODUCTION}

Would it be much of an exaggeration to identify 1990s for Turkish economy as the 'lost decade'?

Turkey initiated its long process of integration with the world commodity and financial markets with the initiation of the structural adjustment programme of 1980 . The process had been completed by the liberalisation of the capital account and identification of full convertibility of the Turkish Lira in 1989. Thus, during the 1990s the Turkish economy operated under the conditions of a 'fully open' macroeconomy. However, the course of integration has not been a smooth one. The decade has been identified by volatile and erratic growth, persistent and high rates of inflation, deteriorating fiscal performance, and a rapidly increasing debt burden. ${ }^{2}$ A number of stabilisation attempts were initiated during the decade to pull the economy out of the traps of capricious growth and unbalanced patterns of accumulation. Most recently in May 2001 a new programme, known as 'Turkey's Program for Transition to a Strong Economy' (TSEP), was introduced with the explicit objective of '.. putting an end to the unsustainable domestic and foreign borrowing dynamics.. ${ }^{3}$ It is aided and technically supported by the International Monetary Fund (IMF), and it incorporates a wide set of issues concerning the financial sector, public sector, agriculture and social security and includes the standard IMF measures: drastic cuts in public spending, monetary contraction, flexible exchange rate management, and reductions in the wage remunerations in public employment. ${ }^{4}$ Nevertheless, the most emphasised goal of the programme is the ensurance of the long-term sustainability of fiscal adjustment and the

${ }^{2}$ See Akyüz and Boratav (2003), Boratav et al. (2002), Yeldan (2002), Ertuğrul and Selçuk (2001), Metin et al. (2001), Cizre-Sakalldoğlu and Yeldan (2000, 2002), Kepenek and Yentürk (2000), Uygur (1996), and Ekinci (1998) for a thorough overview of the post-1990 Turkish macroeconomic history. For the deterioration of fiscal balances see San (2002), Konukman et al. (2000), Özatay (1999), Türel (1999), Selçuk and Rantanen (1996), Atiyas (1995), and Zaim and Taşkın (1997).

3 'Turkey's Program for Transition to a Strong Economy: Introduction', http://www.treasury. gov.tr

${ }^{4}$ In particular, TSEP targeted a primary surplus of $6.5 \%$ of GNP every year until 2006, and aims at reducing the net debt stock of debt to $63.9 \%$ of GNP by the end of that year. It foresees a real rate of growth of $5 \%$ for 2003, 2004 and 2005 and has assumed a nominal interest rate of $46 \%$ for 2003 , $32.4 \%$ for 2004 and $27.4 \%$ for 2005 . The targeted end-of-year inflation rate for wholesale prices has been set at $16.2,12$, and $8 \%$ for the same years, respectively. Thus, the programme implicitly assumes a significant real interest rate throughout implementation. See also the website (www.bagimsizsosyalbilimciler.org) of the Association of the Independent Social Scientists Economists' Group (Bağımsız Sosyal Bilimciler-Iktisat Grubu, 2001) for a set of critical assessments of the 2000-2003 economic policies. 
particular importance attributed to 'budgetary discipline' to attain the 'necessary' primary surpluses.

Given the experience of 1990s, and the uncertain future for the Turkish economy, we believe that it is timely to test the viability of the current IMF-program in Turkey, to study its welfare and growth implications and to investigate the trade offs over inter- and intragenerational distribution of wealth, accumulation, and growth. Thus, the primary purpose of this study is to investigate the effects of debt management, and government spending on welfare and growth, in a debt constrained economy, Turkey.

We attempt to address these issues in the framework of an overlapping generations, small open economy model of endogenous growth, and study the effects of fiscal and social policies of the government under the constraints of debt servicing and a binding fiscal gap. We focus on three sets of issues: First, the model is calibrated to generate an approximate macroeconomic panorama of 1990s for the Turkish economy. Next, we try to view the path of the model economy under alternative fiscal programmes, focusing on macrovariables such as production, investment and growth as well as economic welfare across generations. In the first policy simulation exercise, we study the specifics and the expected macroeconomic consequences of the current austerity programme, TSEP, as implemented under close IMF supervision. The distinguishing characteristic of the simulation is the attainment of primary surplus targets as set out in the official TSEP and the Letter of Intent documents that followed. Finally, as an alternative policy environment, we simulate a fiscal expenditure-cum-tax reform strategy. Here, rather than focusing on the stabilisation of debt dynamics through primary fiscal surpluses, the objective is to implement selective tax reforms and to support an increased public expenditure programme on education. The resulting trade-off between the attainment of fiscal targets and growth of the economy suggests that a mixed programme is likely to produce superior economic outcomes.

The paper is organised as follows: in the next section we provide an overview of the endogenous growth literature with human capital (education)-driven specifics, and highlight the recent advances in the OLG modeling literature that pertain to our analysis. The algebraic set up of the model is introduced in the subsequent section. In the section thereafter, we first provide a broad overview of the Turkish economy over the 1990s. Then we highlight the details of our calibration strategy to track the macroeconomic performance of the Turkish economy in that period. We implement our policy simulation exercises in the penultimate section. The last section summarises and concludes. 


\section{ANTECEDENTS OF THE HUMAN CAPITAL-DRIVEN OLG FRAMEWORK}

Recent advances in the 'new growth theory' identify and emphasise the role of human capital and its rate of accumulation as the key determinants in explaining disparity across countries in macrovariables such as productivity, income per capita and the rate of growth. Barro and Sala-i Martin (1995) point to the significance of both the stock of human capital (part of which is the school enrolment rates and the government expenditures on education as a ratio to GNP) as important determinants of economic growth. Among the studies that document the importance of human capital in the context of conditional convergence and persistent economic growth are Romer (1989), and Barro (1991). More recent surveys such as Temple (1999, 2001a) and Ahn and Hemmings (2000) emphasise the macroeconomic evidence on the productivity benefits of human capital accumulation and education.

Recent models provide evidence regarding human capital as one of the key determinants of economic growth, following the theoretical contributions of Uzawa (1965) and Lucas (1988). In what follows, the process of accumulation of human capital, as affected through the education system and the pivotal role played by both the private and public funds and public policy have been topics of crucial importance for many researchers of the theory and empirics of growth. ${ }^{5}$

In the Lucas (1988) model, the level of output is a function of the stock of human capital, which is generated as a result of a recursive production function on itself. The embedded externality emanating from accumulation of an educated labour force (human capital) serves as the engine of growth. The significance of educational funding to generate human capital and the provision of such funds to education investments in a large number of countries, has led to an increased awareness of education as the ultimate engine of growth, inviting many researchers to analyse the associated welfare effects. ${ }^{6}$

From such a perspective, educational attainment is also regarded as one of the key factors influencing the distribution of income both across households and labour categories. On the one hand, educational attainment and an individual's stock of human capital formation enable its owner to obtain better-paying jobs, more bargaining power and flexibility in the job market. On the other hand, initial distribution of wealth and household

\footnotetext{
${ }^{5}$ A rigorous survey can be found in Aghion and Howitt (1998, Chapter 10). See also Bils and Klenow (2000), Romer (2000) and Temple (2001a,b).

${ }^{6}$ Educational spending is one of the largest expenditure categories in developed economies. In US, the average education expenditures is just under 7\% of GDP (Bowles, 1999). Public and private expenditures on educational institutions accounts for over $6 \%$, or roughly $\$ 1550$ billion of the collective GDP of the OECD member countries each year (Temple, 2001a).
} 
income have a direct impact on the family's capacity to invest in its offspring's human capital formation, as most of the investments in education are made when agents are young. This two-way causality between income distribution and investment in human capital signifies that families who are on the bottom of the strata of income ladder and are dependent on subsistence earnings, could be caught in a low-education, low-income trap. Hence, the manner in which society stratifies will automatically determine who has access to education, what skill levels are accumulated, and, therefore, the patterns of income distribution.

Under these conditions, provision of public funds to education and the government's ability to invest in education and human capital formation play a crucial role in both attaining greater equality and in promoting growth. ${ }^{7}$ Yet, educational spending for accumulation of human capital as the engine of growth has an enormous public component, which makes it a typical example of 'publicly provided private goods'. Traditionally, the amount of schooling provided is heavily dependent on the public sector. In US, $55 \%$ of the education expenditures is provided by government, enrolling $89 \%$ of all school children. Similar data from the OECD suggest not only relatively large contributions of public spending on education and training, it also suggests that government is typically the provider of the majority of public education and training services (OECD, 2000). In most developing countries, education is considered as a priority to reduce poverty and to achieve sustained growth. Barro (1991), Tanzi and Chu (1998), Jung and Thorbecke (2003) and Gupta and Verhoeven (2001) are among the studies that emphasise the importance of education and both the size and efficiency of public education expenditures in improving economic growth. ${ }^{8}$ Such observations bring issues of human capital formation and optimal design of public policies in terms of investments in education, fiscal debt management, and the inter-household and inter-generational burden of taxation to the fore.

In our model, the main interest is inter- and intra-generational distribution effects of government policies on the Turkish economy. In particular, we find it appropriate to work on a framework of finite-lifetimes. The OLG model is a dynamic structure within a general equilibrium framework in which agents' demand functions are based on microfoundations. This framework has traditionally based the process of

\footnotetext{
${ }^{7}$ Perhaps the best known paper on the subject of public education is Stiglitz (1974). Among other seminal references are Glomm and Ravikumar (1992), St Paul and Verdier (1993), Fernandez and Rogerson (1995).

${ }^{8}$ According to the Ministry of Education, in 2001-2002, in Turkey, $96 \%$ of all the schools are public schools, $98 \%$ of the schoolchildren are educated in public schools which employ $95 \%$ of the teachers: http://www.meb.gov.tr.
} 
accumulation of wealth on Modigliani and Brumberg (1954)'s 'life cycle theory'. Agents save and dis-save at different stages of their lives to smooth consumption. The characteristics of the OLG model make it possible to study a large set of economic issues including aggregate implications of life-cycle savings by individuals and effects of redistributive government policies on capital formation and economic growth. Moreover, the OLG structure characterises generations not only by their age, but also by their wealthendowment. Each period, agents will be at different stages of their lifetime planning, and therefore, will be affected differently by any policy action taken by the government.

One of the early applications of debt management in finite horizons is that of Blanchard (1985). Jones and Manuelli (1992) highlight the role of government as an income re-distributor in an OLG framework, which allows for persistent growth. Likewise, Buiter and Kletzer $(1991,1995)$ use OLG models to present their theoretical analysis of fiscal policies.

Ni and Wang (1994) and Glomm and Ravikumar (1997), both under the assumption of finite lifetimes, let public spending on education directly enter the production function of human capital. Ni and Wang (1994) adopt the theoretical framework of Becker and Barro (1988), and Becker et al. (1990), and examine the role of public expenditures on human capital formation. In their model, public spending on education is financed by an income tax. Glomm and Ravikumar (1997), in turn, focus on the growth effects of productive government spending and growth-maximising level of taxation in a dynamic general equilibrium model. More recently, Jung and Thorbecke (2003) analyse the impact of public education expenditure on human capital and its distributional consequences within a multi-sector CGE model for Tanzania and Zambia.

The main reference to large-scale OLG models is Auerbach and Kotlikoff (1987). In this seminal work, growth is exogenous. Yet, by building up a model with 55 overlapping generations, the authors look at a large set of fiscal issues including deficit finance, changes in the level and timing of government spending, choice of tax base, social security and demographic changes. Auerbach and Kotlikoff model has been considered as the most appropriate quantitative model to study dynamic aspects of fiscal policies under finite lifetimes and has motivated a number of OLG studies such as Hviding and Mérette (1998), Fougère and Mérette (1999), Auerbach et al. (1989), Knudsen et al. (1997), Jensen et al. (1998) and Fehr (1999) ${ }^{9}$. Hviding

\footnotetext{
${ }^{9}$ A survey of general large scale dynamic OLG models following Auerbach and Kotlikoff (1987) can be found in Voyvoda (2003, Chapter 3). Fehr (1999, Chapter 1) provides a beneficial survey of dynamic approaches to fiscal policies.
} 
and Mérette (1998) and Fougère and Mérette (1999) investigate the macroeconomic effects of pension reforms in the context of demographic transitions. Both studies focus on the aging problem in OECD economies and analysing pension funding alternatives. The latter model extends the former by employing endogenous growth features under human capital accumulation. The DREAM (Danish Rational Economic Agents Model) by Knudsen et al. (1997) and Jensen et al. (1998) are studies built for Danish economy. Both models, although constructed in different market structure settings, investigate macroeconomic and distributional effects of various fiscal policies. Fehr (1999) primarily studies the welfare effects of income tax reform, pension reform and public debt policy in an exogenous growth model. In an endogenous growth model, where savings takes place in the form of both physical and human capital, Mérette (1998) investigates the effects of alternative debt-reduction policies. This model represents a small open economy calibrated to match Canadian data. His analysis investigates how transferring the government solvency burden of future generations to current generations affects growth and inter-generational welfare. The simulations show that growth can vary significantly during the transition from a high to a low debt-GDP ratio. GDP rises in the long run, and in general, old generations suffer small welfare deteriorations, while welfare of future generations rises significantly.

Thus, a more general aim of this study is to contribute to this literature by investigating the growth and welfare effects of fiscal policies of financing of public spending on education within the context of an OLG model of the Turkish economy. In the next section, we provide a brief overview of the salient features of our model.

\section{THE ALGEBRAIC STRUCTURE OF THE OLG MODEL}

The model here can be regarded as a small open economy version of the Auerbach and Kotlikoff (1987) model. Here, individual labour supply is inelastic. However, each individual entering the labour force is endowed with a given level of human capital through a human capital accumulation function. There are no intentional bequest motives. ${ }^{10}$

The economy consists of overlapping generations of finitely lived individuals who are assumed to have $G$ periods to live, starting from the time they enter the workforce. During the first $G W$ periods, the individual

\footnotetext{
${ }^{10}$ No bequest motive either in the form of physical or human capital (education) is a strong simplification given the effect of intergenerational altruism on capital accumulation of the economy and given the behaviour of a typical Turkish household.
} 
works, receives wage income and profits, which she divides between consumption, taxes from labour and capital income and savings. In the last $(G-G W)$ periods, the agent is retired and consumes her accumulation of assets. So, at any point in time, there are $G$ overlapping generations in the economy, $G W$ working, and $(G-G W)$ retired. Households are assumed to be rational, having perfect foresight.

There is a single production sector that behaves competitively. A single commodity is produced under a neo-classical production technology, using capital and effective labour. Output is either consumed by domestic households, or exported. The government generates revenues through direct taxation of both types of factor income, issues both domestic and foreign debt, and spends its income on purchases of goods, or invests in education.

Financing of the loanable funds for capital accumulation is secured by a 'financial' intermediary. The intermediary collects domestic and foreign savings as well as the interest on previously issued government debt, and the rental on accumulated stock of physical capital in production. These funds are used for: (i) new physical capital accumulation, (ii) interest payments to domestic residents and abroad, and (iii) the public sector borrowing requirement. The intermediary in the current model has no independent objective function nor incentives for positive profits. It simply acts as a means of collecting and re-distributing the loanable funds of the economy.

The algebraic structure of the model is separated into several sets of equations relating to human capital accumulation, household behaviour, production sector, government, capital intermediary, the foreign sector and the aggregation and equilibrium conditions. We discuss each of these sets in detail below.

\section{Human capital accumulation}

In what follows, subscript $t$ stands for the time period and subscript $g$ stands for the age group. The aggregate variables appear in capital letters while the variables at individual level come in small letters.

At any date $t, n_{1, t}$ individuals enter the workforce and the basic educational system endows each of these entrants with a human capital stock $h_{1, t}$ which is generated according to an accumulation function of the form:

$$
h_{1, t}=H\left(h_{1, t-1}, G E_{t-1}\right)
$$

where $G E_{t-1}$ is public expenditures on education in period $t-1 .{ }^{11}$

\footnotetext{
${ }^{11}$ The generic formulation is adopted from Glomm and Ravikumar (1997). Because the focus is on fiscal policy and the distinction between government productive and unproductive expenditures, the human capital accumulation function in Equation (1) is chosen.
} 
One way to interpret the sequence of human capital endowments is as follows: The time until an agent enters the workforce is the education period of learning and acquiring skills. During this education period, individuals accumulate human capital according to the learning technology given in equation (1), by inelastically allocating their time to learning.

Under the current setup, $G$ is set to 30 and $G W$ to 24 ; thus, there are 30 overlapping generations, 24 working and 6 retired at each point in time. Assuming that every agent enters the workforce at the age of 16 years, retires at the age of 64 years and lives until 76 years, each period in the model can be regarded as 2 years. So, $g=1$ indicates the age group 16-17 years old and $g=30$ refers to the age group 74-75 years old. Throughout the simulations, population growth rate is assumed zero, keeping the population of each generation constant at some $n_{g, t}=n$ for all $(g, t)$. Each of the $n$ agents entering the workforce at time $t$ accumulates its human capital through the specification:

$$
h_{1, t}=\delta h_{1, t-1}+\lambda G E_{t-1}
$$

where $(1-\delta)$ is the exogenous depreciation rate of human capital (skills) and $\lambda$ measures the rate at which government spending on education enhances the human capital of an agent born at time $t .{ }^{12}$ We shall call $\lambda$ effective rate of human capital investment. $\lambda$ is one of the calibrated parameters in the model. An agent, once endowed with her human capital entering the workforce, maintains that level throughout her lifespan.

\section{Households}

We work with a representative agent for each generation in the economy. Each individual, once entered into the working life, derives utility from consuming $c c_{g, t}$ units of consumption good when she lives her gth period at time $t$. Domestic good and imports form the consumption composite along a convex isoquant yielding the consumer maximum level of satisfaction.

${ }^{12}$ Such a specification of the human capital production function creates a dynamic externality between generations as pointed out by Lucas (1988). Empirically, Borjas (1992) presents evidence for human capital externalities by showing that the average level of human capital of the previous generations positively affect the current generation's productivity level. This specification leads to a sustained growth path despite the constant returns to scale technology of the economy. Thus, human capital accumulation in this model constitutes the ultimate driving force of growth in the model. See Romer $(1990,1992)$ for more exposition and see Jones (1997) for a critical assessment of the human capital led specifications of sustained growth. 
Formally, an agent entering the workforce at time $t$ is assumed to have preferences of the generic form: ${ }^{13}$

$$
U_{t}\left(c c_{1, t}, c c_{2, t+1}, \ldots, c c_{G, t+G-1}\right)=\sum_{g=1}^{G} \beta^{g-1} u\left(c c_{g, t+g-1}\right)
$$

Here, $\beta$ is the discount factor, $0<\beta<1, u$ is the current period utility function. $^{14}$

Specifically, we use the following constant intertemporal elasticity of substitution (CES) type utility function:

$$
U=\frac{1}{1-\gamma} \sum_{g=1}^{30}\left(\frac{1}{1+\rho}\right)^{g-1} c c_{g, t+g-1}^{1-\gamma}
$$

where $\rho$ stands as the pure rate of time preference and $\gamma$ is the inverse of the intertemporal elasticity of substitution.

The optimisation problem of the representative agent is subject to the physical wealth accumulation conditions. Each agent, following the education period enters the workforce in time $t$ with zero level of initial physical assets and $h_{1, t}$ level of human capital. The current period budget constraint of a member of the workforce is given by

$$
\begin{aligned}
a_{g+1, t+g}-a_{g, t+g-1}= & \left(1-\tau_{i}\right)\left[\left(1-\tau_{w}\right) w_{t+g-1} h_{g, t+g-1}\right. \\
& \left.+\left(1-\tau_{r}\right) r_{t+g-1} a_{g, t+g-1}\right]-c_{g, t+g-1}
\end{aligned}
$$

where $a_{g, t}$ is the physical wealth asset of an individual of age $g$ at time $t, w_{t}$ is the effective wage and $r_{t}$ is the interest rate. $\tau_{i}, \tau_{w}, \tau_{r}$, and are tax rates on aggregate gross income, wages and profits, respectively. When an individual is a member of the active population, she inelastically supplies her labour endowment to production and allocates disposable income in consumption and saving. During the periods of retirement, she consumes her accumulation of assets.

Differentiating the household utility function with respect to $c c_{g, t}$, subject to individual's lifetime budget constraint, yields the following first-order

${ }^{13}$ The period of education is assumed to bring no utility to the agent.

${ }^{14}$ Here, the current period utility function $u(c)$ is continuously differentiable, strictly increasing, strictly concave and homothetic. It turns out that the homotheticity of $u$ allows a balanced growth path under labour-augmenting technology. See Caballé (1998). 
(Euler) condition for consumption:

$$
c c_{g+1, t+1}=\left(\frac{1+r_{t+g}\left(1-\tau r_{t+g}\right)}{1+\rho}\right)^{1 / \gamma} c c_{g, t+g-1}, \quad g=1, \ldots, 29
$$

\section{The production sector}

Firms face competitive output and input markets to maximize profits. Nonnegative quantities of the two factors of production, human capital (or efficiency units of labour) and physical capital can be varied costlessly. All firms are identical. The representative firm's production function exhibits non-increasing returns to scale in its two factors of production, increasing in both arguments, strictly concave, twice continuously differentiable and satisfies Inada conditions. No depreciation is assumed on the part of physical capital. The good produced is either consumed in the domestic market or exported.

Specifically, the production technology is represented by a simple CobbDouglas form depending on physical capital and effective labour force. ${ }^{15}$

$$
X_{t}=A X K_{t}^{\alpha} L_{t}^{1-\alpha}
$$

where $X$ is the real output, $A X$ is the technology-scale parameter, $\alpha$ is the capital income share, $K$ is the stock of physical capital and $L$ is the stock of effective labour. In equilibrium, $L$ is given by the summation of human capital factor of each cohort, multiplied by the population of the working generations.

$$
L_{t}=\sum_{g=1}^{24} h_{g, t} n_{g, t}
$$

Factor demands are obtained from profit maximization decision of the firms with

$$
\begin{gathered}
r_{t}=\alpha A X K_{t}^{\alpha-1} L_{t}^{1-\alpha} P X_{t} \\
w_{t}=(1-\alpha) A X K_{t}^{\alpha} L_{t}^{-\alpha} P X_{t}
\end{gathered}
$$

${ }^{15}$ Cobb-Douglas function in a numerical model is regarded as a plausible specification. Stokey and Rebelo (1995), for instance, report that the elasticities of substitution in production are rather insignificant for the quantitative impact of fiscal experiments. 


\section{Government}

Government enters the economy in several ways including lump-sum transfers, public good expenditures, management of the pension system, and debt accumulation. Yet, in the current model the analysis is focused on productive versus non-productive government spending. We hypothesise that the government spends on education of the young, levies taxes on wage and capital incomes, pays interest on its debt, and borrows to finance any excess of current spending over current revenue. The government's single period budget identity is given by

$$
B_{t+1}-B_{t}=r_{t} B_{t}+G C_{t}+G E_{t}-T_{t}
$$

where $B_{t}$ is the outstanding government debt and $T_{t}$ is the total tax revenues of the government at time $t . G C_{t}$ represents government noneducation expenditures. Here $G C_{t}$ and $G E_{t}$ add up to total government expenditures, $G_{t}$.

It is assumed that the government has no other income than what it collects through general taxes and does not invest in physical capital. ${ }^{16}$ The tax income of the government is determined as a function of proportional taxes on disposable income $\tau_{i}$, labour income $\tau_{w}$, and capital income $\tau_{\mathrm{r}}$ :

$$
\begin{aligned}
T_{t}= & \tau_{i}\left[\sum_{g=1}^{24}\left(1-\tau_{w}\right) w_{t} h_{g, t} n_{g, t}+\sum_{g=1}^{30}\left(1-\tau_{r}\right) r_{t} a_{g, t} n_{g, t}\right] \\
& +\tau_{w} \sum_{g=1}^{24} w_{t} h_{g, t} n_{g, t}+\tau_{r} \sum_{g=1}^{30} r_{t} a_{g, t} n_{g, t}
\end{aligned}
$$

\section{The intermediary}

All the capital accumulation and expenditures in the economy are mediated through an artificial borrowing-lending structure called the intermediary. Here, the intermediary acts as an accounting identity that accumulates the loanable funds:

$$
R I_{t}=S_{t}^{P}+r_{t} B_{t}+r_{t} K_{t}+S_{t}^{F}
$$

where $S_{t}{ }^{P}$ and $S_{t}^{F}$ represent the aggregate savings by domestic residents and foreigners, respectively. The amount of $r_{t} B_{t}$ gives the interest earnings of the

${ }^{16}$ We resort to this specification to avoid making ad hoc assumptions regarding public sector's saving and investment decisions. 
intermediary on current debt of the government, and $r_{t} K_{t}$ gives the rent on capital stock used in production. ${ }^{17}$

The intermediary disposes its funds on the interest payments for servicing its foreign and domestic lenders, to meet the investment demand for physical capital, and to purchase newly issued government debt:

$$
E I_{t}=I_{t}+r_{t} A_{t}+r_{t} B I_{t}^{F}+D_{t}
$$

Here, $A_{t}=\sum a_{g, t}$ represents the aggregate stock of assets in the economy, held by domestic residents. $I_{t}=K_{t+1}-K_{t}$, is the gross investment in physical capital in period $t . D_{t}=B_{t+1}-B_{t}$, is current period budget deficit. $B I_{t}^{F}$, likewise is the foreign debt of the intermediary. We assume no speculative arbitrage gains through the operations of the intermediary, since in a deterministic model such a specification would be implausible. Hence, net profits of the intermediary are zero.

Under the current setup, each period the government deficit $D_{t}$ is financed by newly issued bonds, whose only buyer is the intermediary. The intermediary itself creates a market for both the domestic and foreign savings. ${ }^{18}$ Equation (14) describes the crowding-out effects of government's debt instruments (GDIs) on the loanable funds market. Under the assumption of perfect substitutability, the newly issued debt directly constrains the funds available for new investments in physical capital.

Consequently, if we represent the portion of government debt financed by the accumulations of domestic residents by $\mathrm{BI}_{t}{ }^{D}$, the following identity arises:

$$
B I_{t}^{D}+B I_{t}^{F}=B_{t} \quad \forall t
$$

\section{Foreign trade}

The model, under the assumption of the small open economy, regards world prices of imports (PWM) and exports (PWE) as exogenously given. Domestic imports and exports functions are derived through the so-called Armingtonian commodity specification in traditional CGE modelling exercises. Accordingly, within each financial sector, the domestically produced good $(D C)$, the imports $(M)$ and exports $(E)$ are differentiated from each other by way of imperfect substitutability. Product differentiation in this context, is specified by functions of elasticity of substitution and elasticity of

\footnotetext{
${ }^{17}$ The deterministic setup of the model avoids incorporation of any risk-premium or arbitrage on government debt. The interest rate of the model is equal to the marginal productivity of capital.

${ }^{18}$ This should not be considered as a secondary market though, under the assumption of zero profits for the intermediary.
} 
54

transformation. Then,

$$
\begin{gathered}
C C_{t}=a c\left(b c M_{t}^{-v}+(1-b c) D C_{t}^{-v}\right)^{-\left(\frac{1}{v}\right)} \\
X S_{t}=a t\left(b t E_{t}^{\mu}+(1-b t) D C_{t}^{\mu}\right)\left(\frac{1}{\mu}\right)
\end{gathered}
$$

Given the import-domestic good relative price ratio, cost minimising amount of imports each period is $M_{t}$. Similarly, faced with a relative export-domestic good price ratio, producer maximises its revenues at the export allocation $E_{t}$.

The aggregate demand for imports and export earnings determination lead to the following balance of payments equation:

$$
P W M_{t} M_{t}+r_{t} B I_{t}^{F}=P W E_{t} E_{t}+S_{t}^{F}
$$

Here, $B I_{t}^{F}$ is the debt of the intermediary held by foreigners and $S_{t}^{F}$ is their savings. The 'rest of the world' earns interest on the debt it holds each period. Since debt is issued only by the government sector in this model, in fact, $B I_{t}{ }^{F}$ turns out to be the debt of the government held by foreigners. The 'financial' transactions however, are administered through the intermediary.

\section{Aggregation and equilibrium conditions}

In order to ensure that the model is in macroequilibrium, the following conditions are introduced.

Resource. constraint on the physical capital stock requires that physical capital and government debt held by domestic residents equals total private wealth every period:

$$
K_{t}+B_{t}=\sum_{g} a_{g, t} n_{g, t}+B I_{t}^{F}
$$

Since in each period the sum of physical investments equals the additions to the capital stock, equation (19) shows how, in equilibrium, the debt servicing requirements by the government constrains the economy's capacity to generate investments, therefore capital accumulation, and real growth.

Total receipts by the intermediary has to be equal to its total expenditures, so:

$$
R I_{t}=E I_{t}
$$

Finally, we have the resource constraint for an open economy:

$$
K_{t+1}-K_{t}=Y_{t+1}-C C_{t}-r_{t} B_{t}^{F}+B_{t+1}^{F}-B_{t}^{F}
$$


In this model, the steady state is a perpetual general equilibrium where all real values grow at a constant rate. More formally, we have a steady state in the model economy, when, (i) perfect foresight consumers derive savings supply and demand for consumption good by the intertemporal optimisation of their utility functions (equation (4)) subject to their accumulation constraint (equation (5)) (ii) the firm, takes as given the factor prices, derives their demands and supplies output by profit maximisation by satisfying equations (7)-(11), (iii) the government budget constraint is satisfied, (iv) equilibrium and accounting conditions are satisfied, (v) effective wage rate $w_{t}$ and profit rate $r_{t}$ become stationary, and (vi) levels of flow and stock variables are growing at the constant steady state growth rate, given the education expenditure profile of the public sector.

\section{OVERVIEW OF TURKISH ECONOMY}

\section{Main traits of the Turkish economy in the 1990s}

In this section, we briefly explain the calibration of the model to track the Turkish economy of 1990s. First we give a broad overview of the Turkish economy in the 1990s.

Table 1 portrays the evolution of macro-fundamentals of the Turkish economy throughout 1990s. At first glance, the table reveals that the Turkish growth experience throughout 1990s has been on a fluctuating trend, starting at $9.4 \%$ in 1990 , decreasing to $0.3 \%$ in 1991 and even reaching $-6.1 \%$ during the crisis of 1994. Concomitant with this observation is the cyclical behaviour of consumption and investment. The $20 \%$ decline in public expenditures in 1988 did not recover until 1996-1997. Private investments were also not on a sustained path. The peak of private capital accumulation in 1993 at $38.8 \%$ was immediately followed by the contraction of 1994, and thus, the overall expansion of both private and public capital accumulation could not be sustained.

One of the major signs of the vulnerability of the Turkish macroeconomic balances in 1990s has been continued inflation. Price inflation, which reached a plateau of $60-65 \%$ in 1980 s, accelerated after 1998 and reached a new plateau of $75-80 \%$. One of the main reasons for persistent inflation rates in the Turkish economy has been the deterioration in the fiscal balances of the public sector and the resulting borrowing requirements. The table reflects that the public sector borrowing requirement (PSBR) ratio stood around $10 \%$ on average between 1990-1999, and continued to rise then after. The ratio of public deficit to PSBR, which had been in the order of $40-50 \%$ until 1994, increased to $76.9 \%$ in 1995 and $113.5 \%$ in 2002 . 


\begin{tabular}{|c|c|c|c|c|c|c|c|c|c|c|c|c|c|}
\hline & 1990 & 1991 & 1992 & 1993 & 1994 & 1995 & 1996 & 1997 & 1998 & 1999 & 2000 & 2001 & 2002 \\
\hline \multicolumn{14}{|l|}{ Annual rate of growth } \\
\hline GNP & 9.4 & 0.3 & 6.4 & 8.1 & -6.1 & 8.0 & 7.1 & 8.3 & 3.9 & -6.1 & 6.3 & -9.5 & 7.8 \\
\hline Private & 20.6 & 8.1 & 3.3 & 38.8 & -9.6 & 9.8 & 9.2 & 9.7 & -8.2 & -17.8 & 15.9 & -34.8 & -7.2 \\
\hline Public & 6.7 & 12.7 & 2.2 & 14.1 & -39.5 & -7.6 & 33.0 & 26.5 & 13.9 & -8.7 & 19.6 & -22.0 & 14.5 \\
\hline Private consumption & 13.1 & 1.9 & 3.3 & 8.4 & -5.3 & 5.6 & 8.5 & 8.4 & 0.6 & -2.6 & 6.2 & -9.0 & 1.5 \\
\hline \multicolumn{14}{|l|}{ As Share of GNP (\%) } \\
\hline Current account balance & -1.7 & 0.2 & -0.6 & -3.6 & 2.0 & -1.4 & -1.3 & -1.4 & 1.0 & -0.7 & -4.8 & 1.4 & -1.0 \\
\hline Public disposable income & 13.4 & 11.9 & 11.4 & 9.6 & 9.6 & 9.4 & 7.9 & 9.5 & 8.7 & 7.0 & 7.2 & 3.9 & 6.3 \\
\hline Public savings & 3.4 & 0.7 & -0.8 & -2.7 & -1.1 & -0.1 & -1.9 & -1.7 & -2.6 & -6.8 & -5.2 & -9.1 & -6.6 \\
\hline Public investment & 8.6 & 7.6 & 6.8 & 7.3 & 3.6 & 3.8 & 5.3 & 6.0 & 6.3 & 6.6 & 6.9 & 5.9 & 5.8 \\
\hline Public sector borrowing requirement & 7.4 & 10.2 & 10.6 & 12.1 & 7.9 & 5.2 & 8.8 & 7.6 & 9.2 & 15.3 & 12.5 & 16.4 & 12.6 \\
\hline Public debt stock & 47.1 & 49.0 & 52.7 & 55.5 & 71.2 & 60.7 & 65.0 & 66.2 & 70.4 & 85.5 & 89.16 & 147.6 & 82.0 \\
\hline Outstanding domestic debt & 14.4 & 15.4 & 17.6 & 17.9 & 20.6 & 17.3 & 21.0 & 21.4 & 21.7 & 29.3 & 29 & 68.6 & 54.2 \\
\hline Interest payment on domestic debt & 2.5 & 2.7 & 3.1 & 4.2 & 5.9 & 6.0 & 8.9 & 6.7 & 10.6 & 12.7 & 15 & 22.2 & 18.8 \\
\hline Annual inflation rate (CPI) & 60.3 & 66.0 & 70.1 & 66.1 & 106.3 & 93.6 & 80.4 & 85.7 & 90.7 & 70.5 & 39.1 & 68.5 & 29.7 \\
\hline Real interest rate on government bonds & 1.1 & 16.2 & 15.8 & 18.4 & 19.8 & 19.3 & 33.7 & 25.0 & 29.5 & 20.7 & 5.7 & 6.1 & 24.6 \\
\hline \multicolumn{14}{|l|}{ Share in consolidated budget (\%) } \\
\hline Health & 4.7 & 4.6 & 4.7 & 3.9 & 3.5 & 3.3 & 3.0 & 3.2 & 2.6 & 4.1 & 2.5 & 2.3 & 2.7 \\
\hline Education & 13.2 & 14.1 & 14.6 & 14.4 & 11.4 & 10.2 & 7.2 & 8.1 & 8.4 & 7.9 & 7.2 & 6.4 & 7.6 \\
\hline Interest payment on debt & 24.6 & 24.4 & 23.0 & 32.4 & 39.9 & 40.8 & 54.9 & 38.9 & 52.0 & 56.6 & 61.3 & 79.8 & 67.9 \\
\hline
\end{tabular}

Sources: SPO Main Economic Indicators; Undersecretariat of Foreign Trade and Treasury Main Economic Indicators 
A significant constraint on the government's capability to finance this gap was its limited options in borrowings from abroad. Given the fragile asset position of the public sector, government net foreign borrowing was minimal, and in most instances negative. With the advent of full-fledged financial liberalisation after 1989, however, the governments had the opportunity to by-pass the liquidity constraints on its operations. Consequently, the financing of the PSBR relied exclusively on issues of government debt instruments to the internal market - especially to the banking sector.

The stock of securitised domestic debt grew rapidly over the 1990s. The stock of GDIs, was only $6 \%$ of the GNP in 1989 , the year when the capital account liberalisation was completed. By the end of 2001, this ratio reached to $68.6 \%$. Interest costs on domestic debt grew to $22.2 \%$ of the GNP in the same year, increasing almost 10-fold in real terms over the decade (Table 1). As a further comparison, interest costs on servicing the debt reached to $1,010 \%$ of public investments, and to $481 \%$ of the transfers accruing to social security institutions by the end of the decade. The central government budget in Turkey lost its instrumental role in social infrastructure development and long-term growth as domestic debt servicing needs grew.

The outstanding government debt and its composition not only created a financial burden but also had adverse affects on the growth trajectory of the Turkish economy in the 1990s. The share of public spending on education in the consolidated budget decreased from $13.2 \%$ in 1990 to $7.6 \%$ in 2002 .

\section{The calibration procedure}

Large-scale OLG models can be used to analyse the income effects associated with the fiscal policy changes and to provide a framework to analyse quantitatively the transition from one balanced growth path to another. However, due to its complexity, the model does not lend itself to analytical treatment, and under the assumption of perfect foresight, all equations have to be solved simultaneously.

We first calibrated the model to the macroeconomic data set, which is considered as the relative equilibrium of the Turkish economy. ${ }^{19}$ The basic difference in the calibration procedure in an OLG model and a representative agent model is the generation of an 'equilibrium path' as a benchmark, rather than an 'equilibrium point'. The calibrated parameters then are expected to produce the equilibrium path both vertically in time and horizontally across

\footnotetext{
${ }^{19}$ The choice of the 'base-year' in this initial 'fitting' procedure is crucial. Since an 'equilibrium path' is assumed, the base-year should not be a point of 'structural break' or coincide with a period of 'high-frequency' business cycles.
} 
generations. The first step of calibration consists of fitting the 'steady state' version of the model with Turkish data. As described in the previous section, by 1990, full integration of the Turkish economy with the global markets had been completed and the economy had not yet entered the high-frequency boom and bust cycles. So the year 1990 stands as the best candidate to serve as the initial year in fitting the steady-state version of the model. Thus, in this step, we use the database set out and discussed in detail in Köse and Yeldan (1996) and Yeldan (1998), and calibrate the 'structural' parameters of the model. With the calibrated parameters, the model has to generate the data of the initial year 1990, as a solution for a point in the equilibrium path of the economy.

The intertemporal optimisation problem and the resulting consumption pattern for the representative agent in this model is described above in the section Households. Under the assumption of perfect foresight and exogenously given average yearly growth rate, it is possible to derive the lifetime consumption and savings behaviour of this particular agent as functions of the parameters, the wage rate and the interest rate. But, typically, all agents that are alive in the initial period, have also been following the same pattern of lifetime decisions. So, under the steady-state assumption, it is possible to obtain consumption and asset holding profiles for each age group $(g \in\{1,2,3, \ldots, G\})$ by a backward projection of the behaviour of the representative agent that enters the economy at time $t_{0}$, the initial period. Then the behavioural parameters of the model can be calibrated, using the observed values of GNP, total private consumption, aggregate labour supply, and the amount of government debt that is financed by aggregate asset holdings of the domestic households in the initial year data set. ${ }^{20}$

Using 1990 capital income and labour income data, the capital share parameter $\alpha$ is calibrated. ${ }^{21}$ Here, the rate of productivity growth in the labour-augmenting production function is taken to be $3 \%$ per year. The real interest rate is determined endogenously and is equal to the marginal product of capital. The profile of consumption and asset holdings of each generation is derived to be consistent with the aggregate output and aggregate private consumption figures of 1990 . The key parameter to satisfy this consistency is the rate of time preference of private households $\beta(1 /(1+\rho))$, which takes the value of 0.9775 . An estimate of 2 is used for $\gamma$, the inverse of the

\footnotetext{
${ }^{20}$ The model is calibrated with a given amount of foreign debt at this initial steady-state growth path. Buiter (1981) shows that current account deficit is possible along a balanced growth path in a one-good OLG model.

${ }^{21}$ For comparisons of capital share parameter in OECD counties, see Hviding and Mérette (1998). They report values for $\alpha$ between 0.24 and 0.54 under a similar type of production function,
} 
intertemporal elasticity of substitution. ${ }^{22}$ The stock of total physical capital is calibrated using the value of 'total asset accumulation by domestic household'. Once the stocks of both factors of production are known, the scale parameter, $A X$, is easily calibrated. The human capital variable $h_{t}$, is first produced as an index at the steady-state growth path of the economy. Once the amount of government educational spending and aggregate efficiency labour variables are known, it is easy to come up with a value for the effective rate of public educational investment, $\lambda$. The human capital depreciation rate, $\delta$ is set to 0.2 , which is chosen to be higher then the values in the empirical findings of the studies on industrialised countries, documented to lie between 0.02 and 0.04 (Mérette, 1998) ${ }^{23}$ Finally, the tax rates on both types of income are calibrated using the data on total tax payment of 1990.

The second step in producing the benchmark economy is to bring the economy to the base-period (representing 2002-2003 in the model). To be able to reproduce the historically realised trajectory of the macroeconomic variables, and the public sector balances in particular, the model is shocked by imposing the realised increase in public expenditures over the decade. ${ }^{24}$ Here, since public investment on education enters as an input to the production of human capital, it is necessary to decompose the path of total government spending during 1990s into its productive and non-productive components. Table 1 displays the relative behaviour of certain government expenditure items during the decade. The information provided by the table is used to replicate the behavior of government productive and non-productive expenditures in 1990s and to calibrate the share of government education expenditures in the base-period of the model. ${ }^{25}$ As the base-period is reached, it becomes possible to calibrate the parameters that underlie the demand for foreign savings and the stock of foreign debt (shift and share parameters in the Armingtonian commodity specification). The data of ratio of exports to GNP in the base-period is used as an input at this step of the calibration procedure.

${ }^{22}$ The estimates of $\alpha$ and $\beta$ are consistent with the values from other studies on Turkey. See Selçuk (1997) and Mercenier and Yeldan (1999). The value of $\gamma$ is taken to be consistent with the recent estimates. See Attanasio and Weber (1995).

${ }^{23}$ We have chosen a higher rate of depreciation to reflect that a developing economy might not be that effective in passing the externality across generations, over time.

${ }^{24}$ Because we assume no public investment, the variable under consideration at this step is the government expenditures in each period, generating the path of the government debt stock through 1990s.

${ }^{25}$ Note that the parameter representing the share of government productive spending is one of the crucial parameters of the model since the fiscal policy alternatives analysed inevitably depend on the choice of the government funds available for bringing about the accumulative factors of production. 
60

Table 2: Calibration results: parameter values and initial quantities

Technology scale parameter, $A$

Inverse of the intertemporal elasticity of substitution, $\gamma$

Effective rate of public investment on education, $\lambda$

CES function shift parameter, $b c$

CET function shift parameter, at

The calibrated value of total debt stock as a ratio to GNP for the base period $2002-2003$ is $82.58 \%$. Domestic debt ratio to GNP is $57.6 \%$. Government's educational investment corresponds to $2.08 \%$ GNP and constitutes $20.5 \%$ of total public expenditures. Once the composition of government debt is known, it is easy to generate the amount of foreign savings needed to finance the base-period current account deficit. The calibrated values of the parameters and initial quantities are given in Table 2.

\section{POLICY ANALYSIS}

We shall now turn to the discussion on the investigation of fiscal policy alternatives on debt management and public expenditures on education, cohort welfare and growth for the Turkish economy. As the benchmark scenario, the current IMF-led austerity programme driven by the objectives of attaining primary fiscal surpluses is chosen.

\section{Primary surplus programme}

In constructing the baseline scenario, we study the specified and the expected macroeconomic consequences of the current austerity programme, as implemented under the supervision of the IMF. The distinguishing characteristic of the simulation is the attainment of the primary surplus targets as set out during the official implementation of the program. Given the 
current focus of the current austerity programme on attaining significant fiscal surpluses on the non-interest budget, the scenario is distinguished as the 'Primary Surplus Programme' (PSP).

In order to keep maximum consistency for our model with the outlines of the current austerity programme, the primary surplus objective is attained by reducing both types of public expenditures in the model. The funds generated from the reduction of public non-interest expenditures are then channeled into reduction of the outstanding debt of the economy. In other words, to meet the programme goals, the model creates just enough 'government total expenditures' $G_{t}$; to create a pre-determined level of primary surplus (amounting to $6.5 \%$ of GNP) in the first 5 periods of the model. The government expenditures then are allowed to recover gradually decreasing (by $1 \%$ in every 5 years) the required primary surplus ratio; reaching $1.6 \%$ in the long-run. Throughout the simulation no further policy shock on tax revenues is assumed. The ratio of government education expenditures to government total expenditures is kept constant at its base year value. The macro and fiscal results of 'PSP' are given in Table 3. Figure 1 portrays total debt as a ratio to GNP of the alternative policy environments.

The fiscal balances under 'PSP', as illustrated in Table 3, reveal a 'recovery' 'in the fiscal aggregates, following the base-year. As a ratio to GNP, total debt stock is brought down to $75.14 \%$ by period $2022-2023$. The interest rate holds around $10.5 \%$ and the interest burden on the government of the outstanding debt stock only falls to $6.83 \%$ from its base-year value of $9.07 \%$.

The scenario suggests a negative growth rate of savings with $-2.57 \%$ over the period 2004-2013 and $-3.0 \%$ over the period 2024-2033. Under such a path, together with government's primary surplus being channeled into debt and interest re-payments, the growth rate of economy could only be kept at moderate levels. As public funds are reduced forcefully to attain primary surplus targets, production capacity of the economy is affected adversely. Reduction in the public funds for human capital formation causes the growth rate of total output to decrease. This occurs despite the revival of funds for physical capital investment through reductions in the accumulation of domestic debt. Although the average growth rate of the total capital stock during $2004-2013$ is $6.47 \%$, the efficiency labour could only grow by $2.01 \%$ and GNP by $4.12 \%$.

Nevertheless, we do not observe a 'parallel' decrease in total private consumption. The growth rate of consumption initially is higher than that of GNP. So, as a ratio of GNP, private consumption reaches to $67.12 \%$, from its initial base-year value of $63.57 \%$. Here, generations that have been participating in the workforce both before and at the time of the implementation of 'PSP', are the ones that have already passed through the 


\begin{tabular}{|c|c|c|c|c|c|c|c|c|}
\hline & \multicolumn{8}{|c|}{ ‘Primary Surplus Programme (Standard Scenario)' } \\
\hline & $2004-2013$ & & & $2014-2023$ & & $2024-2033$ & & \\
\hline \multicolumn{9}{|l|}{ Average annual (\%) growth rate of } \\
\hline GDP & 4.12 & & & 3.61 & & 3.57 & & \\
\hline Private consumption & 5.07 & & & 3.91 & & 3.22 & & \\
\hline Private savings & -2.57 & & & -2.89 & & -3.00 & & \\
\hline Capital stock & 6.47 & & & 5.35 & & 4.97 & & \\
\hline Efficiency labuor & 2.01 & & & 2.00 & & 2.19 & & \\
\hline \multicolumn{9}{|l|}{ Key macroeconomic variables (as a ratio to GDP) } \\
\hline & 1 & 2 & 3 & 4 & 5 & 8 & 9 & 10 \\
\hline & $2004-2005$ & $2006-2007$ & $2008-2009$ & $2010-2011$ & $2012-2013$ & $2018-2019$ & $2020-2021$ & $2022-2023$ \\
\hline Private consumption & 0.6425 & 0.6486 & 0.6539 & 0.6584 & 0.6628 & 0.6705 & 0.6712 & 0.6712 \\
\hline Private savings & 0.2366 & 0.2214 & 0.2068 & 0.1931 & 0.1804 & 0.1468 & 0.1370 & 0.1280 \\
\hline Private investment & 0.3114 & 0.3066 & 0.3026 & 0.2846 & 0.2814 & 0.2774 & 0.2731 & 0.2743 \\
\hline Capital stock & 4.6079 & 4.7130 & 4.8183 & 4.9236 & 5.0177 & 5.2812 & 5.3651 & 5.4443 \\
\hline Interest rate & 0.1093 & 0.1082 & 0.1071 & 0.1061 & 0.1051 & 0.1022 & 0.1013 & 0.1003 \\
\hline Foreign Savings ${ }^{a}$ & 0.0972 & 0.1044 & 0.1117 & 0.1192 & 0.1270 & 0.1519 & 0.1606 & 0.1696 \\
\hline \multicolumn{9}{|l|}{ Fiscal balances (as a ratio to GDP) } \\
\hline Total debt stock & 0.8139 & 0.8013 & 0.7876 & 0.7725 & 0.7709 & 0.7596 & 0.7537 & 0.7514 \\
\hline Interest on total debt & 0.0874 & 0.0841 & 0.0809 & 0.0777 & 0.0760 & 0.0712 & 0.0695 & 0.0683 \\
\hline Government taxes & 0.1666 & 0.1653 & 0.1639 & 0.1626 & 0.1614 & 0.1576 & 0.1563 & 0.1550 \\
\hline Government expenditures (net of interest payments) & 0.1016 & 0.1003 & 0.0989 & 0.1126 & 0.1114 & 0.1076 & 0.1113 & 0.1100 \\
\hline Education expenditures & 0.0208 & 0.0206 & 0.0203 & 0.0231 & 0.0228 & 0.0221 & 0.0228 & 0.0226 \\
\hline Primary balance & 0.0650 & 0.0650 & 0.0500 & 0.0500 & 0.0500 & 0.0450 & 0.0450 & 0.0450 \\
\hline
\end{tabular}

${ }^{\text {a }}$ Adjusted current account deficit that equals: Merchandise trade deficit + interest payements abroad, not including other factor incomes 


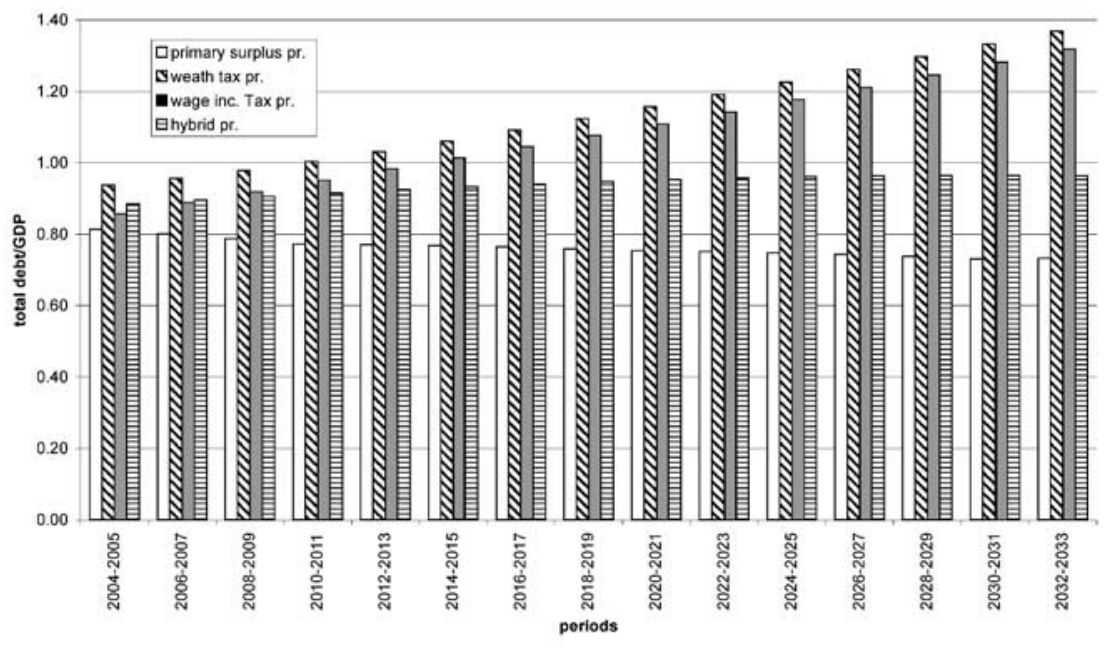

Figure 1: Total Debt Stock as a Ratio to GDP.

education system. Thus, these generations have accumulated their human capital long ago. When the 'PSP' is implemented, funds that are available to education decrease, reducing the growth rate of aggregate amount of effective labour for production. So, generations that have already accumulated their skills, have the chance to earn relatively higher wage incomes. Moreover, these agents are the ones with relatively higher wealth-holdings. As the growth rate of capital is kept above the growth rate of the economy, profit income of these agents rise. Thus 'older' agents are able to allocate more funds to consumption activities, as dictated by the first-order condition of utility maximisation. This gives further stimulus to aggregate consumption, decreasing aggregate savings. On the other hand, government's productive expenditures are now smaller and contribute relatively less to production of human capital for the future generations, causing relative earnings to decrease.

Summing up, the 'PSP', the main objective of which is to generate a certain level of primary surplus through reductions in government expenditures and to allocate the additional funds to reduce the debt stock of the economy, suffers both from the sluggishness of the debt to GNP ratio and a trade-off on growth and fiscal targets. ${ }^{26}$ There is also a trade-off between the welfare of the current and future generations.

\footnotetext{
${ }^{26}$ The question of how the economy would be able to transfer gains in the fiscal balances into real production activities and growth creates an additional ambiguity for 'PSP'.
} 


\section{Wage income tax programme (WITP)}

Given the path of the macroeconomy under 'PSP', it would be pertinent to study various alternatives to mitigate the reduction in the availability of public funds to reproducible factors of production. In designing such alternatives, our objective is to automatically allocate the additional tax revenue not to debt reduction, but to educational funds exclusively.

The first alternative relies on wage income taxation. We first increase the wage income tax rate by $10 \%$ over the current rate of $7 \%$ for five consecutive modeling periods (that would amount to a calendar period of 10 years), starting with 2002-2003. Such a policy generates an additional $10 \%$ wageincome tax revenue each period during its implementation. There are two main hypotheses underlying this experiment: First, the policy environment is 'credible'. In other words, the government succeeds in channeling the additional monies into investments in education, still does not change its behaviour on non-productive spending. Secondly, it is assumed that the policy shocks are unexpected; but once in operation, the agents are informed on the duration and magnitude. Specific to the experiments carried out in this study, every generation of finite lifetimes in the model is assumed to take its lifetime decisions of consumption and savings into account while the policy remains active. Thus, the transitional path analysis here does not take into consideration the generations that might enjoy possible policy changes in the context of debt-sustainability or government solvency in the future.

Table 4 reports on the macroeconomic balances under 'WITP'. The general equilibrium results as deviations from the benchmark scenario are given in Table 5. Figure 2 portrays the growth path in comparison to 'PSP'.

Under the 'WITP', there are significant 'gains' on the production side. As the growth rate of savings turns positive, the growth rate of capital stock is well above the rate under the 'PSP'. The growth rate of the economy stays around $4.45 \%$ on average, over the period 2004-2033, compared with $3.75 \%$ with 'PSP'.

As the current young generations feel the effect of distortionary taxes on their wage income, they tend to increase their savings (See Table 5). However, the increase in savings is not reflected as accumulations to total stock of capital. Since the government is now running a much lower level of primary surplus $(2.5 \%$ as a ratio to GNP), the public sector borrowing requirement increases each period. Thus, although total asset accumulation of the economy continues to stay above its benchmark level, the crowding-out effect of PSBR on the funds available for production causes the total capital stock to stay below its level under 'PSP'. However, observe from Table 4 that as the 'growth' effect dominates, the capital stock available for production revives. 
Table 4: Macroeconomic balances

\begin{tabular}{|c|c|c|c|c|c|c|c|c|c|c|c|c|c|c|c|c|c|c|c|c|c|c|c|c|}
\hline & \multicolumn{8}{|c|}{ 'Wage Income Taxation Program (WITP)' } & \multicolumn{8}{|c|}{ 'Wealth Tax Program (WTP)' } & \multicolumn{8}{|c|}{ 'Hybrid Program (HP)' } \\
\hline & \multicolumn{3}{|c|}{ 2004-2013 } & \multicolumn{2}{|c|}{ 2014-2023 } & \multicolumn{2}{|c|}{ 2024-2033 } & & \multicolumn{2}{|c|}{ 2004-2013 } & \multicolumn{3}{|c|}{ 2014-2023 } & \multicolumn{2}{|c|}{ 2024-2033 } & \multicolumn{3}{|c|}{ 2004-2013 } & \multicolumn{3}{|c|}{ 2014-2023 } & \multicolumn{2}{|c|}{ 2024-2033 } & \\
\hline \multicolumn{25}{|c|}{ Average annual (\%) growth rate of } \\
\hline GDP & 4. & 54 & & 4. & 43 & 4.4 & & & 5. & 76 & & 5.01 & & & .86 & & 5.6 & & & 5.89 & & 6.1 & & \\
\hline Private consumption & 5. & 15 & & 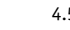 & 52 & 4.0 & & & 5. & 09 & & 5.15 & & & 49 & & 5.4 & & & 5.14 & & 5.0 & 07 & \\
\hline Private savings & 0. & 89 & & 1. & 06 & 1.1 & 18 & & 4. & 38 & & 3.52 & & & .99 & & 3.7 & 78 & & 3.86 & & 3.9 & 98 & \\
\hline Capital stock & 6. & 02 & & 5. & 60 & 5.4 & & & 6. & 35 & & 6.48 & & & .20 & & 6.5 & & & 6.83 & & 7.1 .1 & 10 & \\
\hline Efficiency labour & 3. & 11 & & 3. & 35 & 3.3 & 36 & & 5. & 37 & & 3.75 & & & .58 & & 4.7 & & & 4.88 & & 5.0 & 08 & \\
\hline \multicolumn{25}{|c|}{ Key Macroeconomic Variables (As a ratio to GDP) } \\
\hline & 1 & 2 & 3 & 4 & 5 & 8 & 9 & 10 & 1 & 2 & 3 & 4 & 5 & 8 & 9 & 10 & 1 & 2 & 3 & 4 & 5 & 8 & 9 & 10 \\
\hline & $\begin{array}{c}2004- \\
2005\end{array}$ & $\begin{array}{c}2006- \\
2007\end{array}$ & $\begin{array}{c}2008- \\
2009\end{array}$ & $\begin{array}{c}2010- \\
2011\end{array}$ & $\begin{array}{c}2012- \\
2013\end{array}$ & $\begin{array}{c}2018- \\
2019\end{array}$ & $\begin{array}{c}2020- \\
2021\end{array}$ & $\begin{array}{c}2022- \\
2023\end{array}$ & $\begin{array}{c}2004- \\
2005\end{array}$ & $\begin{array}{c}2006- \\
2007\end{array}$ & $\begin{array}{l}2008- \\
2009\end{array}$ & $\begin{array}{c}2010- \\
2011\end{array}$ & $\begin{array}{c}2012- \\
2013\end{array}$ & $\begin{array}{c}2018- \\
2019\end{array}$ & $\begin{array}{c}2020- \\
2021\end{array}$ & $\begin{array}{c}2022- \\
2023\end{array}$ & $\begin{array}{l}2004- \\
2005\end{array}$ & $\begin{array}{c}2006- \\
2007\end{array}$ & $\begin{array}{c}2008- \\
2009\end{array}$ & $\begin{array}{c}2010- \\
2011\end{array}$ & $\begin{array}{c}2012- \\
2013\end{array}$ & $\begin{array}{c}2018- \\
2019\end{array}$ & $\begin{array}{c}2020- \\
2021\end{array}$ & $\begin{array}{r}2022- \\
2023\end{array}$ \\
\hline
\end{tabular}

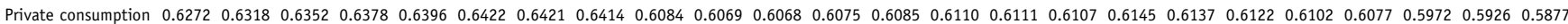
$\begin{array}{llllllllllllllllllllllllll}\text { Private savings } & 0.2561 & 0.2466 & 0.2382 & 0.2305 & 0.2234 & 0.2029 & 0.1967 & 0.1908 & 0.2845 & 0.2809 & 0.2756 & 0.2694 & 0.2627 & 0.2422 & 0.2358 & 0.2297 & 0.2723 & 0.2669 & 0.2619 & 0.2573 & 0.2530 & 0.2419 & 0.2389 & 0.2361\end{array}$ $\begin{array}{lllllllllllllllllllllllll}\text { Private investment } & 0.2822 & 0.2784 & 0.2756 & 0.2738 & 0.2766 & 0.2766 & 0.2777 & 0.2794 & 0.3114 & 0.3066 & 0.3026 & 0.2846 & 0.2814 & 0.2774 & 0.2731 & 0.2743 & 0.3082 & 0.3100 & 0.3124 & 0.3154 & 0.3189 & 0.3326 & 0.3382 & 0.3443\end{array}$ $\begin{array}{llllllllllllllllllllllllll}\text { Capital stock } & 4.5851 & 4.6570 & 4.7212 & 4.7790 & 4.8317 & 4.9949 & 5.0486 & 5.1020 & 4.4526 & 4.4724 & 4.5088 & 4.5561 & 4.6106 & 4.7946 & 4.8587 & 4.9231 & 4.5277 & 4.5738 & 4.6193 & 4.6644 & 4.7091 & 4.8426 & 4.8877 & 4.9334\end{array}$

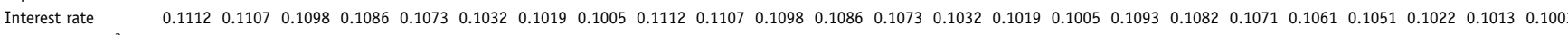
$\begin{array}{llllllllllllllllllllllllllll}\text { Foreign savings }^{\mathrm{a}} & 0.0975 & 0.1050 & 0.1127 & 0.1207 & 0.1290 & 0.1554 & 0.1648 & 0.1744 & 0.0982 & 0.1057 & 0.1134 & 0.1214 & 0.1296 & 0.1556 & 0.1646 & 0.1739 & 0.0977 & 0.1050 & 0.1125 & 0.1202 & 0.1281 & 0.1525 & 0.1608 & 0.1692\end{array}$

Fiscal Balances (As a ratio to GDP)

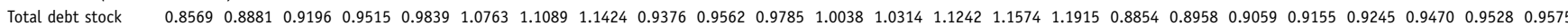

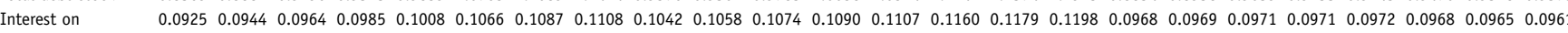
total debt

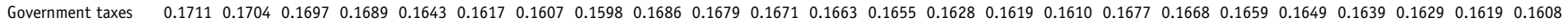
Government $\begin{array}{lllllllllllllllllllllllll}0.1461 & 0.1454 & 0.1446 & 0.1439 & 0.1393 & 0.1357 & 0.1348 & 0.1338 & 0.1436 & 0.1429 & 0.1421 & 0.1413 & 0.1405 & 0.1378 & 0.1369 & 0.1360 & 0.1327 & 0.1318 & 0.1309 & 0.1299 & 0.1289 & 0.1258 & 0.1247 & 0.1236\end{array}$ (net of interest payments)

Education

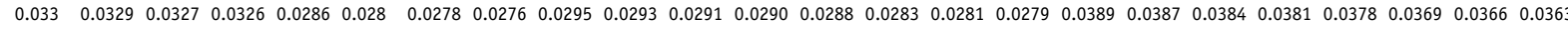
expenditures

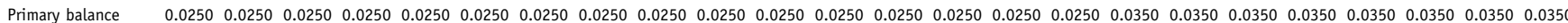
के: adjusted current account deficit which equals: Merchandise trade deficit+interest payements abroad, not including other factor incomes. 
66

Table 5: General equilbrium results (ratio of deviation from the primary surplus programme)

\begin{tabular}{|c|c|c|c|c|c|c|c|c|}
\hline & \multicolumn{8}{|c|}{ EXP1, 'WITP' } \\
\hline & 1 & 2 & 3 & 4 & 5 & 8 & 9 & 10 \\
\hline & $\begin{array}{c}2004- \\
2005\end{array}$ & $\begin{array}{c}2006- \\
2007\end{array}$ & $\begin{array}{c}2008- \\
2009\end{array}$ & $\begin{array}{c}2010- \\
2011\end{array}$ & $\begin{array}{c}2012- \\
2013\end{array}$ & $\begin{array}{c}2018- \\
2019\end{array}$ & $\begin{array}{c}2020- \\
2021\end{array}$ & $\begin{array}{c}2022- \\
2023\end{array}$ \\
\hline GDP & 0.9988 & 1.0002 & 1.0036 & 1.0089 & 1.0165 & 1.0403 & 1.0484 & 1.0569 \\
\hline Private consumption & 0.9751 & 0.9743 & 0.9749 & 0.9774 & 0.9810 & 0.9964 & 1.0030 & 1.0100 \\
\hline Private savings & 1.0812 & 1.1140 & 1.1560 & 1.2044 & 1.2588 & 1.4379 & 1.5053 & 1.5755 \\
\hline Total assets & 1.0027 & 1.0063 & 1.0108 & 1.0165 & 1.0234 & 1.0508 & 1.0618 & 1.0737 \\
\hline Capital stock & 0.9939 & 0.9883 & 0.9834 & 0.9793 & 0.9788 & 0.9839 & 0.9866 & 0.9905 \\
\hline Efficiency labour & 1.0037 & 1.0120 & 1.0239 & 1.0388 & 1.0549 & 1.0987 & 1.1128 & 1.1264 \\
\hline Total wage income & 0.9879 & 0.9709 & 0.9577 & 0.9475 & 0.9394 & 0.9211 & 0.9160 & 0.9113 \\
\hline Total profit income & 1.0077 & 1.0183 & 1.0317 & 1.0471 & 1.0629 & 1.1108 & 1.1285 & 1.1456 \\
\hline Foreign savings & 1.0015 & 1.0059 & 1.0128 & 1.0221 & 1.0326 & 1.0645 & 1.0757 & 1.0867 \\
\hline \multicolumn{9}{|l|}{ Fiscal balances } \\
\hline Total taxes & 1.0256 & 1.0308 & 1.0389 & 1.0478 & 1.0348 & 1.0674 & 1.0780 & 1.0897 \\
\hline $\begin{array}{l}\text { Total expenditures (net of } \\
\text { interest payments) }\end{array}$ & 1.4360 & 1.4498 & 1.4672 & 1.2896 & 1.2711 & 1.3212 & 1.2788 & 1.2952 \\
\hline Education expenditures & 1.5830 & 1.5989 & 1.6189 & 1.4236 & 1.2711 & 1.3212 & 1.2788 & 1.2952 \\
\hline \multirow[t]{4}{*}{ Total debt stock } & 1.0515 & 1.1085 & 1.1719 & 1.2428 & 1.2974 & 1.4739 & 1.5427 & 1.6069 \\
\hline & \multicolumn{8}{|c|}{ EXP2, 'WTP' } \\
\hline & 1 & 2 & 3 & 4 & 5 & 8 & 9 & 10 \\
\hline & $\begin{array}{c}2004- \\
2005\end{array}$ & $\begin{array}{c}2006- \\
2007\end{array}$ & $\begin{array}{c}2008- \\
2009\end{array}$ & $\begin{array}{c}2010- \\
2011\end{array}$ & $\begin{array}{c}2012- \\
2013\end{array}$ & $\begin{array}{c}2018- \\
2019\end{array}$ & $\begin{array}{c}2020- \\
2021\end{array}$ & $\begin{array}{c}2022- \\
2023\end{array}$ \\
\hline GDP & 1.0111 & 1.0301 & 1.0479 & 1.0649 & 1.0821 & 1.1294 & 1.1446 & 1.1598 \\
\hline Private consumption & 0.9574 & 0.9639 & 0.9724 & 0.9826 & 0.9934 & 1.0292 & 1.0421 & 1.0553 \\
\hline Private savings & 1.2158 & 1.3070 & 1.3966 & 1.4857 & 1.5757 & 1.8634 & 1.9700 & 2.0813 \\
\hline Total assets & 1.0056 & 1.0150 & 1.0273 & 1.0418 & 1.0581 & 1.1152 & 1.1365 & 1.1588 \\
\hline Capital stock & 0.9770 & 0.9776 & 0.9806 & 0.9854 & 0.9943 & 1.0254 & 1.0365 & 1.0487 \\
\hline Efficiency labour & 1.0456 & 1.0844 & 1.1184 & 1.1490 & 1.1756 & 1.1994 & 1.2613 & 1.2800 \\
\hline Total wage income & 1.0111 & 1.0301 & 1.0479 & 1.0649 & 1.0821 & 1.1294 & 1.1446 & 1.1598 \\
\hline Total profit income & 1.0407 & 1.0698 & 1.0978 & 1.1258 & 1.1516 & 1.2283 & 1.2550 & 1.2814 \\
\hline Foreign savings & 1.0213 & 1.0433 & 1.0645 & 1.0851 & 1.1044 & 1.1570 & 1.1736 & 1.1895 \\
\hline \multicolumn{9}{|l|}{ Fiscal balances } \\
\hline Total taxes & 1.0232 & 1.0464 & 1.0684 & 1.0891 & 1.1096 & 1.1667 & 1.1856 & 1.2047 \\
\hline $\begin{array}{l}\text { Total expenditures (net of } \\
\text { interest payments) }\end{array}$ & 1.4291 & 1.4676 & 1.5049 & 1.3364 & 1.3646 & 1.4467 & 1.4082 & 1.4339 \\
\hline Education expenditures & 1.4291 & 1.4676 & 1.5049 & 1.3364 & 1.3646 & 1.4467 & 1.4082 & 1.4339 \\
\hline \multirow[t]{4}{*}{ Total debt stock } & 1.1647 & 1.2293 & 1.3021 & 1.3838 & 1.4478 & 1.6715 & 1.7578 & 1.8390 \\
\hline & \multicolumn{8}{|c|}{ EXP3, 'HP' } \\
\hline & 1 & 2 & 3 & 4 & 5 & 8 & 9 & 10 \\
\hline & $\begin{array}{c}2004- \\
2005\end{array}$ & $\begin{array}{c}2006- \\
2007\end{array}$ & $\begin{array}{c}2008- \\
2009\end{array}$ & $\begin{array}{c}2010- \\
2011\end{array}$ & $\begin{array}{c}2012- \\
2013\end{array}$ & $\begin{array}{c}2018- \\
2019\end{array}$ & $\begin{array}{c}2020- \\
2021\end{array}$ & $\begin{array}{c}2022- \\
2023\end{array}$ \\
\hline GDP & 1.0059 & 1.0189 & 1.0341 & 1.0512 & 1.0710 & 1.1379 & 1.1629 & 1.1895 \\
\hline Private consumption & 0.9620 & 0.9641 & 0.9681 & 0.9742 & 0.9819 & 1.0135 & 1.0267 & 1.0415 \\
\hline
\end{tabular}


E Voyvoda \& E Yeldan

\begin{tabular}{|c|c|c|c|c|c|c|c|c|}
\hline Private savings & 1.1576 & 1.2283 & 1.3096 & 1.4007 & 1.5020 & 1.8751 & 2.0279 & 2.1941 \\
\hline Total assets & 1.0046 & 1.0114 & 1.0206 & 1.0319 & 1.0455 & 1.0989 & 1.1210 & 1.1453 \\
\hline Capital stock & 0.9884 & 0.9888 & 0.9914 & 0.9959 & 1.0051 & 1.0434 & 1.0594 & 1.0779 \\
\hline Efficiency labour & 1.0233 & 1.0493 & 1.0777 & 1.1084 & 1.1397 & 1.2388 & 1.2741 & 1.3101 \\
\hline Total wage income & 1.0070 & 1.0187 & 1.0303 & 1.0419 & 1.0536 & 1.0938 & 1.1092 & 1.1254 \\
\hline Total profit income & 1.0225 & 1.0422 & 1.0646 & 1.0891 & 1.1140 & 1.1984 & 1.2305 & 1.2638 \\
\hline Foreign savings & 1.0109 & 1.0254 & 1.0420 & 1.0606 & 1.0800 & 1.1425 & 1.1647 & 1.1871 \\
\hline \multicolumn{9}{|l|}{ Fiscal balances } \\
\hline Total taxes & 1.0125 & 1.0282 & 1.0467 & 1.0661 & 1.0876 & 1.1610 & 1.1882 & 1.2171 \\
\hline $\begin{array}{l}\text { Total expenditures (net of } \\
\text { interest payments) }\end{array}$ & 1.3140 & 1.3394 & 1.3679 & 1.2131 & 1.2397 & 1.3301 & 1.3029 & 1.3363 \\
\hline Education expenditures & 1.8799 & 1.9162 & 1.9570 & 1.7356 & 1.7736 & 1.9030 & 1.8640 & 1.9117 \\
\hline Total debt stock & 1.0941 & 1.1391 & 1.1894 & 1.2457 & 1.2843 & 1.4186 & 1.4702 & 1.5157 \\
\hline
\end{tabular}

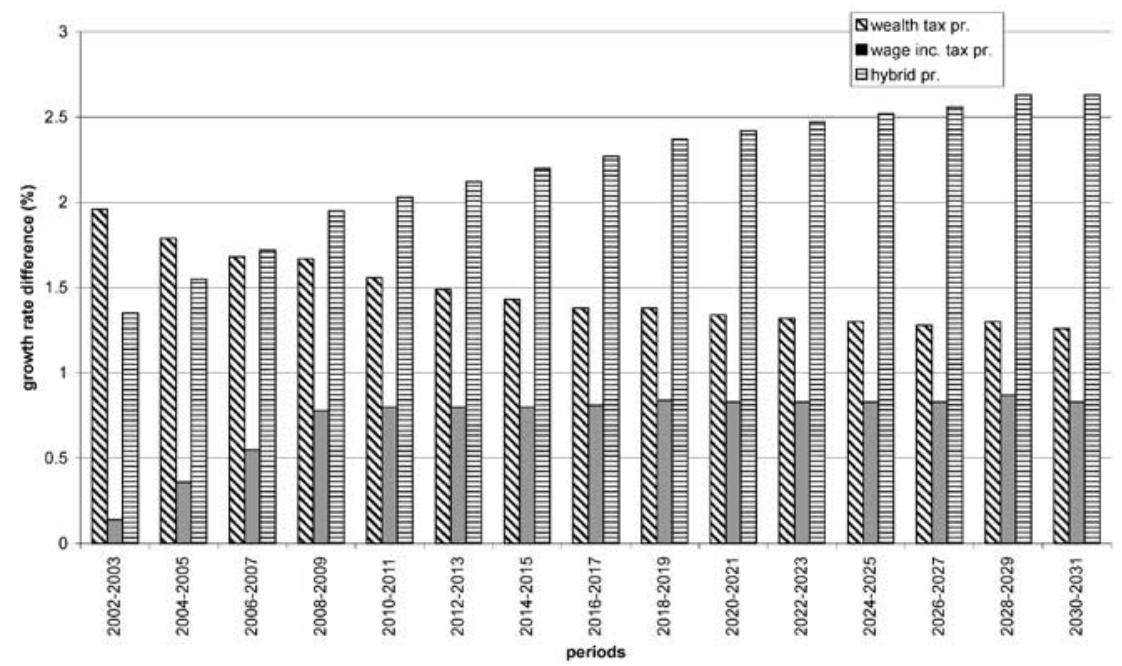

Figure 2: Growth rate differences w.r.t 'primary surplus programme'.

The availability of additional funds to human capital accumulation increases the growth rate of efficiency labour, and keeps total labour input for production well above the 'PSP'. However, the source of the additional funds is wage-income. So, as future generations enjoy 'possible gains' from additional funds to education, the generations that are currently working suffer from losses. Thus, while the profit income level is above the 'PSP', the wage-income follows a path below, causing the aggregate consumption variable to decrease with respect to 'PSP' in the short-to-medium run, until the growth effects are in charge. 
Looking at the fiscal balances on the other hand, we observe reversed results of the 'PSP'. We observe that growth of the tax revenues falls short of the government expenditures deteriorating fiscal balances. Consequently, the ratio of the total debt to GNP starts to increase from a level of $85.69 \%$ immediately after the introduction of the policy and reaches $114.24 \%$ of GNP at the end of the 10th period (year 2022-2023). This amount is 1.6 times greater than 'PSP' level.

Given the acceleration in the rate of growth, the welfare analysis suggests considerable gains in the utility of the upcoming generations. ${ }^{27}$ The methodology followed in creating a measure of welfare is based on King and Rebelo (1990). If we denote $U_{t}\left(\left\{c c_{g l+t-1, t}\right\}_{g l=1}^{30}\right)$ as the lifetime utility of an agent entering the workforce at time $t$, by following the consumption path $\left\{c c_{g l+t-1, t}\right\}_{g l=1}^{30}$ under the benchmark scenario, it is possible to calculate the welfare gain (or loss) associated with a policy shock, $\theta$ as follows: If $U_{t}\left(\left\{c c_{g l+t-1, t}^{\prime}\right\}_{g l=1}^{30}\right)$ is the path of consumption of the agent after the shock, the measure of the welfare gain (loss) in compensating consumption units is the value of $\theta$ such that $U_{t}\left(\left\{c c_{g l+t-1, t}(1-\theta)\right\}_{g l=1}^{30}\right)=U_{t}\left(\left\{c c_{g l+t-1, t}^{\prime}\right\}_{g l=1}^{30}\right)$. Figure 3 shows the welfare gain of all generations (generations entering the workforce before and after base-period 2002-2003) in comparison to 'PSP'. As followed from the figure, the 'WITP' suggests increases in the welfare of both present and future generations. The increase in the welfare of each future generation is quite comparable since these generations are the ones that take advantage of the additional funds to education to increase their efficiency, thus their wage earnings. The relatively high growth rate on the other hand, prevents the compensating consumption units of the generations who pay for the additional taxes to turn negative. The relative loss of wage income is made up for by the relative gain in the profit income through increased interest rates. ${ }^{28}$ Given the dismal outcome on the fiscal front, crucial questions remain: would there be a critical level of additional tax revenues such that, while keeping the advantages of high growth rates and gains in aggregate output, will not allow the fiscal balances' deterioration to overcome the positive effects in the production side of the economy? What would be the main principle of a tax/ expenditure reform programme that would meet the servicing obligations of the outstanding debt, while not hampering the positive externalities on future production?

\footnotetext{
${ }^{27}$ The assumption in carrying out the welfare analysis is that neither current nor the future generations involved in the analysis are obliged to bear any effects of the policy maneuvers to reduce the debt/GNP ratio.

${ }^{28}$ Note once more that the interest rate is elementally equal to marginal productivity of capital in the model.
} 


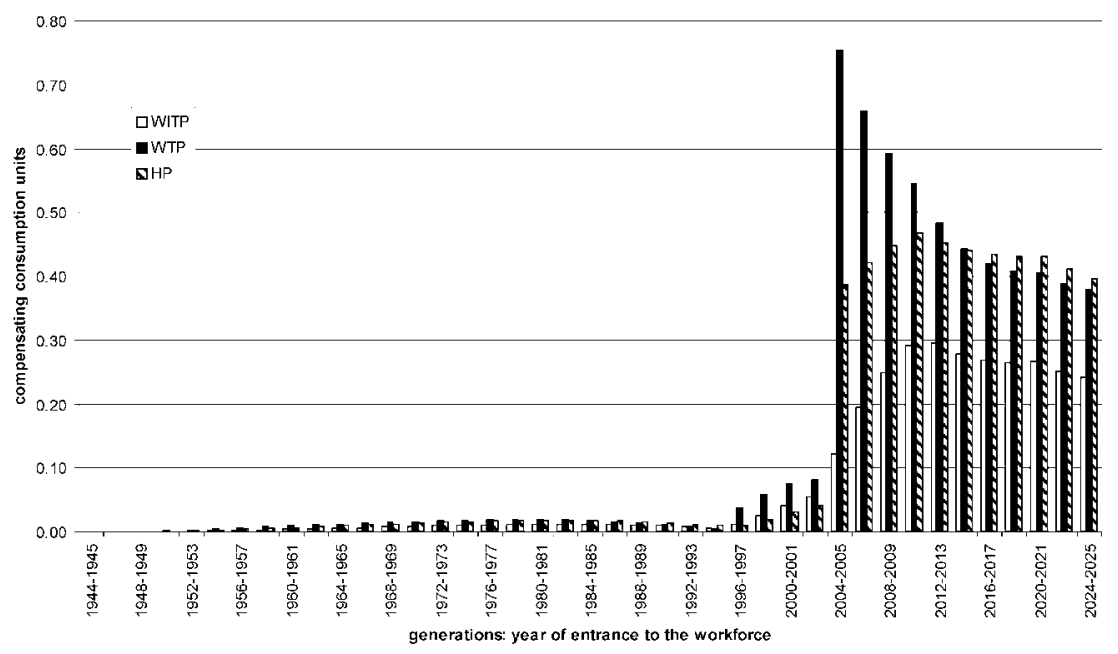

Figure 3: Welfare analysis w.r.t 'primary surplus programme'.

We now turn towards these questions and simulate a fiscal expenditurecum-tax reform strategy. Here, once more the focus is on implementing a selective tax reform, this time on the stock of assets (wealth income). The exclusive focus is to support an increased public expenditure program addressed to finance public investments on education. The next sub-section investigates this policy scenario.

\section{Wealth tax programme}

In this scenario, a temporary tax on wealth incomes is introduced. The tax rate is set as $2 \%$ in the initial period (note that given the real life projection covers a period of 2-years, such a policy shift becomes effective over 20022003). In the model, this amounts to an additional tax revenue of $10.3 \%$ of GNP and $59.7 \%$ of the current tax revenues. Like the 'WITP', the additional tax revenues are included in the public funds used for accumulation of human capital.

The growth consequences of the policy are found to be quite strong. The growth rate of GNP is 1.5 percentage points higher than the 'PSP' growth rate on average (See Table 4). Private consumption recovers more quickly then it does in 'WITP', after the tax shock. The aggregate saving variable reaches to two-folds of its level under 'PSP' by the period 2022-2023.

The path of debt accumulation, on the other hand, could not be brought under control more successfully than the previous tax reform program on 
wage incomes. Total debt stock as a ratio to GNP at the end of the fifth period (year $2012-2013$ ) is $103.14 \%$ and is $119.5 \%$ of GNP at the end of the 10th period. These figures amount to 1.34 and 1.042 times higher than their levels under 'WITP'. Note that, the growth effect under 'WTP' is quite powerful and the growth rate of total debt stock decreases in the medium-to-long run.

It could be observed from Figure 3 that the older generations who have already accumulated substantial amount of assets are protected from welfare losses through the imposition of the wealth tax, by the associated growth effects of the policy. Total profit income remains higher than both 'PSP' and 'WITP' levels. On the other hand, there are comparable gains in the welfares of future generations starting with the one entering the workforce in period 2004-2005. Following a period of transition, such gains are stabilized.

Given the complexity and variety of the above results, the natural questions to ask are what kind of a tax programme would be more plausible and socially realistic? Is it possible to design an hybrid programme that will not inherit the 'unsustainable' characteristics of the fiscal balances and achieve comparable growth rates for both consumption and savings, thus growth?

The first alternative scenario analysed here depends on the wage income taxation which would be the easiest to implement in the Turkish context. However, a $10 \%$ increase for 10 (calendar) years on wage incomes is neither politically realistic nor desirable from an egalitarian point of view. Moreover, note that although both 'WITP' and 'WTP' generated comparable debt to GNP ratios, the revenue extracted from wage income taxation is much lower than the revenue obtained by wealth income taxation. ${ }^{29}$ While taxation of wealth incomes promises a more desirable outcome in terms of growth, it still cannot keep the economy away from experiencing an unsustainable debt path.

\section{A hybrid programme}

Both the 'WITP' and 'WTP' provide comparable gains in the growth rate of the economy, since more funds are allocated for human capital accumulation through public education. But the path of the total debt stock turns out to be unsustainable under both taxation programmes. There are two reasons for the behavior of the debt stock. One reason is that neither 'WITP' nor 'WTP' include strict primary surplus targets as in 'PSP'. The other reason is due to

\footnotetext{
${ }^{29}$ In a similar model, we ask the question of by how much should the tax rate on wage incomes had to be increased to obtain the amount of revenue as in a 'WTP' scenario with a $5 \%$ additional tax rate on wealth incomes. The finding is that the wage tax rate had to be increased by $60 \%$ over its current level in order to generate the same amount of revenue obtained form the implementation of wealth tax.
} 
the distortionary effects of taxation on capital accumulation. Although the efficiency labour units stay above the level under 'PSP', the decrease in capital stock as a result of taxation of both types of income hinders the growth effect from creating enough resources to generate a stationary debt stock series in the economy.

The 'HP' is a compounded programme involving features of both taxation and fiscal prudence. Formally, a $1 \%$ tax on wealth incomes is imposed for one period (2002-2003). Accompanying this tax policy a $3.5 \%$ ratio of primary surplus to GNP is achieved. However, unlike the 'PSP' scenario, in order for such a policy not to contract the government's funds available for accumulation of productive inputs, the surplus objective is mostly achieved through reductions in the government non-productive expenditures. For this, the share of government consumption variable, $G C_{t}$ in total government expenditures (net of interest payments) is reduced by $10 \%$. Such a treatment of the government sector keeps the government education expenditures at an amount of $3.8 \%$ of GNP on average in the first 10 periods of the model horizon. This value is greater than the value generated by additional (temporary) funds to education spending.

The revival of the funds to government educational spending causes the efficiency labour to grow at an average rate of $4.89 \%$. As the additional taxes generated from wealth incomes is now less than the amount under 'WTP', the distortionary effects are not that strong and with a growth rate of $6.87 \%$ on average, the capital stock recovers more quickly to generate the best growth performance among the alternative policy scenarios (see Figure 2). The growth rate of output is $5.66 \%$ on average for the first five periods of the model horizon, which generates a 7\% higher GNP then the 'PSP' in level terms at the end of the fifth period. Likewise, the total assets, private savings and both wage and profit incomes show considerable gains in comparison to 'PSP'. Besides, a 'sustainable' pattern of total debt stock as a ratio to GNP is attained. Starting from the base-year value of $82.58 \%$, initially, this variable is observed to increase under the policy, reaching to $92.45 \%$ in the fifth period (year 2012-2013). Yet, it is stabilised at around 95\% thereafter. Unlike the 'WTP' that generates exploding paths for the ratio of debt stock to GNP, the 'HP' involving less-distortionary effects and more funds to the accumulation of productive factors generate rather 'smooth' path.

The welfare analysis of 'HP' suggests further favorable results. Although the increased funds to education is not as high as the amount in 'WTP', the pattern is more smooth in changing the patterns of accumulation of the capital stock, and as the economy revives from the constraining effects of the debt management, welfare gains of the future generations are 'stabilised'. And as the economy continues to grow at the highest rate among the alternatives 
considered, the 'HP' displays a comparable utility advantage to future generations.

\section{CONCLUDING COMMENTS}

In this paper, we studied the welfare and growth implications of various fiscal policy alternatives for the Turkish economy over the 2000s. The current IMFled austerity program which is planned to be in operation at least until 2004 is criticised heavily in that it gives priority to targets on fiscal debt rather than growth, and implements an implicit preference for finance over industry. Furthermore, the programme is accused of lacking credible public support and of general ignorance on its social welfare implications.

Thus, given the dubious macro-policy environment, we attempted to investigate the growth and welfare consequences of the current austerity program as well as the various alternatives of taxation and fiscal expenditures. To this end, we made use of an endogenous growth, overlapping-generations model, calibrated to Turkish data over 1990s. First, we studied the implications of the austerity program focusing exclusively on fiscal balances. We maintained the fiscal targets of the TSEP to attain a primary surplus of $6.5 \%$ as a ratio to GNP until 2004 to be complemented by equilibrium in the primary balance of the public sector then after.

As simulated over the time horizon as above, the model results forcefully disclose the tacit dilemma of the 'primary surplus programme' The attainment of fiscal targets to maintain the warranted rates of primary surplus deprives the social/productive spheres of the economy from the most needed public funds to maintain the social capital investments on education. The numerical results of the model suggest that with the implementation of such a programme, the fiscal debt constraint could be resolved but the productive sphere of the real economy might be severely hampered.

The results further indicated that a compound (hybrid) programme with the objective of reviving the most-needed public funds for accumulation of productive factors in order to achieve sustained growth is likely to produce superior outcomes compared with the alternatives of fiscal prudence and distortionary taxation. Although wage income taxation is arguably the easiest to implement given the Turkish tax structure, it would likely to suffer from social and political constraints. Admitting that a tax programme over wealth incomes would necessitate a strong bureaucracy and a well-administered taxation regime, the model results here emphasise that alternatives on fiscal programming do exist. Nevertheless, the model indicates that what is needed is a 'general equilibrium' approach in investigating the distortionary effects of 
taxation on accumulation patterns of the economy, and to address the dilemmas that policy alternatives possess.

Clearly, a promising avenue of further research within our theoretical framework would be building larger scale general equilibrium models where rational agents with finite lifetimes and a public sector with an infinite time horizon interact within a 'more realistic' market setting. In contrast to simple models, large-scale models would enable one to consider simultaneous changes in a variety of fiscal instruments and provide ways to understand short-to-medium run responses by making it possible to observe the transition paths of the modelled economies. The large-scale models, with assumptions of longer timespans on the part of each individual would provide more realistic setups that will point to the income distribution effects of permanent policy changes. This would be more conducive in addressing the political economy dilemmas likely to be faced in real policy setting. These issues, of course are beyond the scope of the current model, which we merely consider as an initial step to understand how the economies work and move over time.

\section{REFERENCES}

Aghion, P and Howitt, C. 1998: Endogenous Growth Theory. MIT Press: Cambridge.

Ahn, S and Hemmings, P. 2000: Policy influences on economic growth in OECD countries: An evaluation of evidence. OECD Economics Department Working papers, No. 246, OECD: Paris.

Akyüz, Y and Boratav, K. 2003: The making of the Turkish financial crisis, paper prepared for the conference "Financialization of the Global Economy". World Development 31(9): $1549-1566$.

Atiyas, I. 1995: Uneven governance and fiscal failure: the adjustment experience of Turkey. In: Frischtak, L and Athiyas, I (eds). Governance, Leadership, and Communication: Building Constitutiences for Economic Reform. World Bank: Washington, DC. Chapter 9.

Attanasio, OP and Weber, G. 1995: Is consumption growth consistent with intertemporal optimization? Evidence from consumer expenditure survey. Journal of Political Economy 103: $1121-1157$.

Auerbach, AJ and Kotlikoff, LJ. 1987: Dynamic Fiscal Policy. Cambridge University Press: Cambridge, UK.

Auerbach, AJ, Kotlikoff, LJ, Hagemann, RP and Nicoletti, G. 1989: The economic dynamics of an ageing population: The case of four OECD countries. OECD Economic Studies No. 12, OECD: Paris.

Bağımsız Sosyal Bilimciler İktisat Grubu. 2001: Güçlü ekonomiye geçiş programı üzerine değerlendirmeler www.bagimsizsosyalbilimciler.org/iktisat.htm.

Barro, RJ. 1991: Economic growth in a cross section of countries. Quarterly Journal of Economics 106(2): 407-443.

Barro, RJ and Sala-i Martin, X. 1995: Economic Growth. McGraw-Hill: Singapore.

Becker, GS and Barro, RJ. 1988: A reformulation of economic theory of fertility. Quarterly Journal of Economics 103: 1-25.

Becker, GS, Murphy, KM and Tamura, R. 1990: Human capital, fertility and economic growth. Journal of Political Economy 98: S12-S37. 
Bils, M and Klenow, PJ. 2000: Does schooling cause growth? American Economic Review 90(5): 1160-1183.

Blanchard, OJ. 1985: Debts, deficits and finite horizons. Journal of Political Economy 93: 223-247.

Boratav, K, Yeldan, E and Köse, A. 2002: Globalization, distribution and social policy: Turkey: 1980-1998. In: Taylor, L (ed). External Liberalization and Social Policy. Oxford University Press: London and New York.

Borjas, GJ. 1992: Ethnic capital and intergenerational mobility. Quarterly Journal of Economics 107(1): 123-150.

Bowles, RZ. 1999: Essays in public education. PhD Thesis, Virginia Polytechnic Institute and State University, Virginia.

Buiter, WH and Kletzer, KM. 1995: Capital mobility, fiscal policy and growth under self-financing of human capital formation. Working paper No. 5120, NBER: Cambridge, MA.

Buiter, WH. 1981: Time preference and international lending and borrowing in an overlappinggenerations model. Journal of Political Economy 89: 769-797.

Buiter, WH and Kletzer, KM. 1991: The welfare economics of cooperative and non-cooperative fiscal policy. Journal of Economic Dynamics and Control 15: 215-244.

Caballé, J. 1998: Growth effects of taxation under altruism and low elasticity of intertemporal substitution. The Economic Journal 108: 92-104.

Cizre-Sakallioğlu, Ü and Yeldan, E. 2002: Turkey: Economy, politics and society in the post-crisis Era. Mimeo.

Cizre-Sakallioğlu, Ü and Yeldan, E. 2000: Politics, society and financial liberalization: Turkey in the 1990s. Development and Change 31(1): 481-508.

Ekinci, N. 1998: Türkiye ekonomisinde geli ${ }^{\circ}$ menin dinamikleri ve kriz. Toplum ve Bilim 77: 7-27.

Ertuğrul, A and Selçuk, F. 2001: A brief history of Turkish economy, 1990-2000. Russian and East European Finance and Trade 37(6): 54-75.

Fehr, H. 1999: Welfare Analysis of Dynamic Tax Reforms. Mohr Siebeck: Tübingen.

Fernandez, R and Rogerson, R. 1995: On the political economy of education subsidies. Review of Economic Studies 62(2): 249-262.

Fougère, M and Mérette, M. 1999: Population ageing and economic growth in seven OECD countries. Economic Modelling 16: 411-427.

Glomm, G and Ravikumar, B. 1997: Productive government expenditures and long run growth. Journal of Economic Dynamics and Control 21: 183-204.

Glomm, G and Ravikumar, B. 1992: Public vs. private investment in human capital: endogenous growth and income inequality. Journal of Political Economy 100: 818-834.

Gupta, S and Verhoeven, M. 2001: The efficiency of government expenditure: Experiences from Africa. Journal of Policy Modeling 23: 433-467.

Hviding, K and Mérette, M. 1998: Macroeconomics effects of pension reforms in the context of ageing: OLG simulations for seven OECD countries. OECD Working paper no: 201, OECD: Paris.

Jensen, SEH, Nielsen, SB, Pedersen, LH and Sorensen, PB. 1998: Tax policy, housing and the labour market: an intertemporal simulation approach. Economic Modelling 13: 355-382.

Jones, CI. 1997: The upcoming slowdown in US economic growth NBER Working Paper No. 6284 NBER: Cambridge, MA.

Jones, EL and Manuelli, RE. 1992: Finite lifetimes and growth. Journal of Economic Theory 58: 171-197.

Jung, H and Thorbecke, E. 2003: The impact of public education expenditure on human capital, growth and poverty in Tanzania and Zambia: a general equilibrium approach. Journal of Policy Modeling 25: 701-725.

Kepenek, Y and Yentürk, N. 2000: Türkiye Ekonomisi. Remzi Yayınevi: Istanbul. 
King, RG and Rebelo, S. 1990: Public policy and economic growth: developing neoclassical implications. Journal of Political Economy 98: S126-S150.

Knudsen, MB, Pedersen, LH, Petersen, TW, Stephensen, P and Trier, P. 1997: A Prototype of Dream (Danish Rational Economic Agents Model). Mimeo.

Konukman, A, Aydén, A and Oyan, O. 2000: Türk kamu mali yönetiminin yeniden yapılandırılması: tespit ve öneriler. Proceedings of the XV, Turkish Financial Symposium, May, Antalya.

Köse, A and Yeldan, E. 1996: ok sektörlü hesaplanabilir genel denge modellerinin veri tabanỳ üzerine notlar: Türkiye 1990 sosyal hesaplar matrisi. METU Studies in Development 23(1): 59-83.

Lucas, RE. 1988: On the mechanics of economic development. Journal of Monetary Economics 22: $3-44$.

Metin-Özcan, K, Voyvoda, E and Yeldan, E. 2001: Dynamics of macroeconomic adjustment in a globalized developing economy: growth, accumulation and distribution, Turkey 1969-1998. Canadian Journal of Development Studies 22(1): 217--253.

Mercenier, J and Yeldan, E. 1999: How prescribed policy can mislead: a plea for greater attention to data in policy analysis. Journal of Policy Modeling 2(1): 851-873.

Mérette, M. 1998: Tax effect of debt reduction on intergenerational equity and growth: the case of Canada. Mimeo.

Modigliani, F and Brumberg, R. 1954: Utility analysis and the consumption function: An interpretation of the cross-section data In: Kurihara, KK (ed). Post-Keynesian Economics. Rutgers University Press: New Brunswicj, NJ.

Ni, S and Wang, X. 1994: Human capital and income taxation in an endogenous growth model. Journal of Macroeconomics 16: 493-507.

OECD. 2000: Education at a Glance. OECD: Paris.

Özatay, F. 1999: The 1994 currency crisis in Turkey. Policy Reform 1(1): 1-26.

Romer, PM. 1989: Human capital and growth: Theory and evidence. NBER Working paper. NBER: Cambridge, MA.

Romer, PM. 1990: Endogenous technological change. Journal of Political Economy 98(5): S71-S102.

Romer, PM. 1992: Two strategies for economic development: Using ideas and producing ideas. Proceedings of the World Bank Annual Conference on Development Economics. IBRD: Washington, DC, pp. 63-92.

Romer, PM. 2000: Should the government subsidize supply or demand market for scientists and engineers? NBER Working Paper No. 7723, NBER: Cambridge, MA.

San, E. 2002: Sustainability of fiscal policy: the case of Turkey. Unpublished MS Thesis, Middle East Technical University.

Selçuk, F. 1997: Consumption smoothing and current account: Turkish experience 1987-1996. Metu Studies in Development 24: 519-529.

Selçuk, F and Rantanen, A. 1996: Türkiye'de Kamu Harcamaları ve İç Borç Stoku Üzerine Gözlemler ve Mali Disiplin Üzerine Öneriler. TUSIAD Publications: İstanbul.

St. Paul, G and Verdier, T. 1993: Education, democracy and growth. Journal of Development Economics 42: 399-407.

Stiglitz, JE. 1974: On the irrelevance of corporate financial policy. American Economic Review 64(5): 851-866.

Stokey, NL and Rebelo, S. 1995: Growth effects of flat tax rates. Journal of Political Economy 103: 519-550.

Tanzi, V and Chu, K (eds). 1998: Income Distribution and High-quality Growth. MIT Press: Cambridge, MA.

Temple, J. 2001a: Growth effects of education and social capital in OECD countries. OECD Economic Studies No. 33, 200I/II, OECD: Paris.

Temple, J. 2001b: Generalizations that aren't. Evidence on education and growth. European Economic Review 45: 905-918. 
Temple, J. 1999: The new growth evidence. Journal of Economic Literature 27: 112-156.

Türel, O. 1999: Restructuring the public sector in post-1980 Turkey: an assessment. Middle East Technical University ERC Working Papers no. 99/6.

Uygur, E. 1996: Export policies and export performance: The case of Turkey. Mimeo.

Uzawa, H. 1965: Optimal technical change in an aggregative model of economic growth. International Economic Review 6: 18-31.

Voyvoda, E. 2003: Alterantives in debt management: Investigation of Turkish debt in an OLG equilibrium framework. Unpublished Ph.D. Thesis, Bilkent university, Ankara.

Attanasio, OP and Weber, G. 1995: Is consumption growth consistent with intertemporal optimization? Evidence from consumer expenditure survey. Journal of Political Economy 103: 1121-1157.

Yeldan, E. 2002: On the IMF-directed disinflation program in Turkey: A program for stabilization and austerity or a recipe for impoverishment and financial chaos? In: Balkan N and Savran S (eds). The Ravages of Neo-Liberalism: Economy, Society and Gender in Turkey. Nova Science Publications: New York.

Yeldan, E. 1998: On structural sources of the 1994 Turkish crisis: A CGE modeling analysis. The International Review of Applied Economics 12(3): 397-414.

Zaim, O and Taşkın, F. 1997: The comparative performance of the public enterprise sector in Turkey: A malmquist productivity index. Journal of Comparative Economics 25: 129-157.

\section{APPENDIX: A NOTE ON SENSITIVITY ANALYSIS ON MODEL PARAMETERS}

In order to test the sensitivity of the model results to the values adopted for structural parameters, we conducted a revision of the policy scenarios using a wide range of parametric values. We briefly summarise our findings in this appendix.

\section{$(1-\delta)$ : human capital depreciation rate}

Calibrating for a smaller value of $\delta(0.04)$ : A reduction in the value of this parameter reduces the sensitivity of the consequences for growth of a reduction in public spending. Yet, the trade-off between fiscal and growth targets is still visible. The lower depreciation rate for human capital contributes to production of effective labour at a higher rate, thus higher growth rate under 'PSP' is observed. Nevertheless, because of the same reason, programmes that are effective in mitigating the reductions in the public 'productive' spending offers higher growth rates. But, the stabilisation of debt under 'HP' takes a longer time and a higher level of debt stock/GNP ratio (see Tables A1 and A2).

\section{$\lambda$ : effective rate of public education investment}

This parameter can be regarded so as to represent the quality of public investment on effective labour. Given the stock of labour in the initial year (in efficiency units of labour) and the level of public educational spending, $\lambda$ is 
Table A1: Sensitivity analysis: ratio of deviation from the primary surplus programme

\begin{tabular}{|c|c|c|c|c|c|c|c|c|c|c|c|c|c|c|c|}
\hline & \multicolumn{5}{|c|}{ 'WTP' } & \multicolumn{5}{|c|}{ 'WITP' } & \multicolumn{5}{|c|}{ 'HP' } \\
\hline & 1 & 2 & 3 & 4 & 5 & 1 & 2 & 3 & 4 & 5 & 1 & 2 & 3 & 4 & 5 \\
\hline & $\begin{array}{c}2004- \\
2005\end{array}$ & $\begin{array}{c}2006- \\
2007\end{array}$ & $\begin{array}{c}2008- \\
2009\end{array}$ & $\begin{array}{c}2010- \\
2011\end{array}$ & $\begin{array}{c}2012- \\
2013\end{array}$ & $\begin{array}{c}2004- \\
2005\end{array}$ & $\begin{array}{c}2006- \\
2007\end{array}$ & $\begin{array}{c}2008- \\
2009\end{array}$ & $\begin{array}{c}2010- \\
2011\end{array}$ & $\begin{array}{c}2012- \\
2013\end{array}$ & $\begin{array}{c}2004- \\
2005\end{array}$ & $\begin{array}{c}2006- \\
2007\end{array}$ & $\begin{array}{c}2008- \\
2009\end{array}$ & $\begin{array}{c}2010- \\
2011\end{array}$ & $\begin{array}{c}2012- \\
2013\end{array}$ \\
\hline \multicolumn{16}{|c|}{ Low $\delta$ (low human capital depreciation rate) } \\
\hline GDP & 0.9944 & 0.9992 & 1.0043 & 1.0097 & 1.0165 & 0.9971 & 0.9951 & 0.9939 & 0.9934 & 0.9948 & 0.9968 & 0.9997 & 1.0038 & 1.0090 & 1.0165 \\
\hline Capital stock & 0.9750 & 0.9710 & 0.9678 & 0.9654 & 0.9663 & 0.9931 & 0.9864 & 0.9798 & 0.9735 & 0.9702 & 0.9864 & 0.9835 & 0.9812 & 0.9797 & 0.9817 \\
\hline Efficiency labour & 1.0139 & 1.0276 & 1.0413 & 1.0550 & 1.0683 & 1.0011 & 1.0038 & 1.0078 & 1.0133 & 1.0195 & 1.0071 & 1.0160 & 1.0265 & 1.0386 & 1.0519 \\
\hline Total debt stock & 1.1646 & 1.2278 & 1.2985 & 1.3778 & 1.4391 & 1.0513 & 1.1083 & 1.1716 & 1.2424 & 1.2969 & 1.0940 & 1.1385 & 1.1881 & 1.2437 & 1.2813 \\
\hline \multicolumn{16}{|c|}{ Low $\lambda$ (low effective rate of human capital) } \\
\hline GDP & 0.9952 & 1.0007 & 1.0066 & 1.0129 & 1.0206 & 0.9972 & 0.9954 & 0.9944 & 0.9942 & 0.9960 & 0.9972 & 1.0007 & 1.0054 & 1.0113 & 1.0196 \\
\hline Capital stock & 0.9751 & 0.9714 & 0.9686 & 0.9666 & 0.9680 & 0.9932 & 0.9865 & 0.9800 & 0.9738 & 0.9707 & 0.9865 & 0.9837 & 0.9817 & 0.9805 & 0.9829 \\
\hline Efficiency labour & 1.0153 & 1.0304 & 1.0454 & 1.0604 & 1.0750 & 1.0012 & 1.0041 & 1.0086 & 1.0146 & 1.0214 & 1.0078 & 1.0175 & 1.0291 & 1.0424 & 1.0569 \\
\hline Total debt stock & 1.1646 & 1.2279 & 1.2987 & 1.3782 & 1.4398 & 1.0513 & 1.1083 & 1.1717 & 1.2426 & 1.2971 & 1.0940 & 1.1385 & 1.1882 & 1.2439 & 1.2816 \\
\hline \multicolumn{16}{|c|}{ High $\alpha$ (high share of capital income) } \\
\hline GDP & 1.0030 & 1.0165 & 1.0292 & 1.0415 & 1.0543 & 0.9972 & 0.9968 & 0.9985 & 1.0022 & 1.0087 & 1.0019 & 1.0121 & 1.0249 & 1.0400 & 1.0584 \\
\hline Capital stock & 0.9748 & 0.9719 & 0.9711 & 0.9716 & 0.9757 & 0.9926 & 0.9857 & 0.9797 & 0.9746 & 0.9735 & 0.9874 & 0.9864 & 0.9875 & 0.9905 & 0.9986 \\
\hline Efficiency labour & 1.0460 & 1.0857 & 1.1210 & 1.1533 & 1.1815 & 1.0040 & 1.0132 & 1.0268 & 1.0442 & 1.0628 & 1.0236 & 1.0512 & 1.0824 & 1.1171 & 1.1528 \\
\hline Total debt stock & 1.1681 & 1.2432 & 1.3300 & 1.4301 & 1.5112 & 1.0580 & 1.1237 & 1.1983 & 1.2839 & 1.3516 & 1.0975 & 1.1500 & 1.2102 & 1.2793 & 1.3287 \\
\hline
\end{tabular}


Table A2: Sensitivity analysis: debt stock/GNP ratio and growth rate

\begin{tabular}{|c|c|c|c|c|c|c|c|c|c|c|c|c|c|c|c|c|c|c|c|c|}
\hline & \multicolumn{5}{|c|}{ ‘PSP' } & \multicolumn{5}{|c|}{ 'WTP' } & \multicolumn{5}{|c|}{ ‘WITP' } & \multicolumn{5}{|c|}{ ‘HP' } \\
\hline & 1 & 2 & 3 & 4 & 5 & 1 & 2 & 3 & 4 & 5 & 1 & 2 & 3 & 4 & 5 & 1 & 2 & 3 & 4 & 5 \\
\hline & $\begin{array}{l}2004- \\
2005\end{array}$ & $\begin{array}{c}2006- \\
2007\end{array}$ & $\begin{array}{c}2008- \\
2009\end{array}$ & $\begin{array}{c}2010- \\
2011\end{array}$ & $\begin{array}{c}2012- \\
2013\end{array}$ & $\begin{array}{c}2004- \\
2005\end{array}$ & $\begin{array}{c}2006- \\
2007\end{array}$ & $\begin{array}{c}2008- \\
2009\end{array}$ & $\begin{array}{c}2010- \\
2011\end{array}$ & $\begin{array}{c}2012- \\
2013\end{array}$ & $\begin{array}{c}2004- \\
2005\end{array}$ & $\begin{array}{c}2006- \\
2007\end{array}$ & $\begin{array}{c}2008- \\
2009\end{array}$ & $\begin{array}{c}2010- \\
2011\end{array}$ & $\begin{array}{c}2012- \\
2013\end{array}$ & $\begin{array}{c}2004- \\
2005\end{array}$ & $\begin{array}{c}2006- \\
2007\end{array}$ & $\begin{array}{c}2008- \\
2009\end{array}$ & $\begin{array}{c}2010- \\
2011\end{array}$ & $\begin{array}{c}2012- \\
2013\end{array}$ \\
\hline \multicolumn{21}{|l|}{ Original Model } \\
\hline $\begin{array}{l}\text { Total debt } \\
\text { stock/GNP }\end{array}$ & 0.8139 & 0.8013 & 0.7876 & 0.7725 & 0.7709 & 0.9376 & 0.9562 & 0.9785 & 1.0038 & 1.0314 & 0.8569 & 0.8881 & 0.9196 & 0.9515 & 0.9839 & 0.8854 & 0.8958 & 0.9059 & 0.9155 & 0.9245 \\
\hline Growth rate & 1.0438 & 1.0418 & 1.0401 & 1.0380 & 1.0374 & 1.0634 & 1.0597 & 1.0569 & 1.0547 & 1.0530 & 1.0452 & 1.0454 & 1.0456 & 1.0458 & 1.0454 & 1.0573 & 1.0573 & 1.0573 & 1.0575 & 1.0577 \\
\hline \multicolumn{21}{|c|}{ Low $\delta$ (low human capital depreciation rate) } \\
\hline $\begin{array}{l}\text { Total debt } \\
\text { stock/GNP }\end{array}$ & 0.8145 & 0.7991 & 0.7822 & 0.7637 & 0.7589 & 0.9539 & 0.9819 & 1.0114 & 1.0422 & 1.0743 & 0.8588 & 0.8899 & 0.9220 & 0.9552 & 0.9893 & 0.8939 & 0.9100 & 0.9258 & 0.9413 & 0.9565 \\
\hline Growth rate & 1.0473 & 1.0459 & 1.0447 & 1.0424 & 1.0416 & 1.0523 & 1.0512 & 1.0503 & 1.0495 & 1.0487 & 1.0452 & 1.0446 & 1.0442 & 1.0439 & 1.0437 & 1.0504 & 1.0502 & 1.0501 & 1.0501 & 1.0502 \\
\hline \multicolumn{21}{|c|}{ Low $\lambda$ (low effective rate of human capital) } \\
\hline $\begin{array}{l}\text { Total debt } \\
\text { stock/GNP }\end{array}$ & 0.8144 & 0.7987 & 0.7815 & 0.7626 & 0.7571 & 0.9530 & 0.9800 & 1.0082 & 1.0376 & 1.0681 & 0.8586 & 0.8893 & 0.9208 & 0.9530 & 0.9860 & 0.8934 & 0.9088 & 0.9236 & 0.9379 & 0.9517 \\
\hline Growth rate & 1.0476 & 1.0464 & 1.0453 & 1.0432 & 1.0426 & 1.0534 & 1.0526 & 1.0518 & 1.0511 & 1.0506 & 1.0456 & 1.0453 & 1.0451 & 1.0450 & 1.0451 & 1.0512 & 1.0513 & 1.0515 & 1.0517 & 1.0521 \\
\hline \multicolumn{21}{|c|}{ High $\alpha$ (high share of capital income) } \\
\hline $\begin{array}{l}\text { Total debt } \\
\text { stock/GNP }\end{array}$ & 0.6850 & 0.6699 & 0.6529 & 0.6338 & 0.6272 & 0.7977 & 0.8194 & 0.8404 & 0.8437 & 0.8704 & 0.7268 & 0.7552 & 0.7836 & 0.8120 & 0.8404 & 0.7504 & 0.7612 & 0.7710 & 0.7797 & 0.7873 \\
\hline Growth rate & 1.0791 & 1.0751 & 1.0718 & 1.0679 & 1.0664 & 1.0936 & 1.0886 & 1.0845 & 1.0811 & 1.0783 & 1.0787 & 1.0770 & 1.0758 & 1.0748 & 1.0737 & 1.0901 & 1.0887 & 1.0876 & 1.0869 & 1.0864 \\
\hline
\end{tabular}


one of the calibrated parameters of the model, in relation to the human capital depreciation rate, $\delta$. Thus, for a given level of labour stock, $\delta$ and $\lambda$ move together so as to satisfy equation (2) in the model. Therefore, if $\delta$ is reduced from its current value of 0.2 to 0.04 , in calibration, $\lambda$ takes a higher value.

If, for instance, for a constant level of $\delta(0.04), \lambda$ is increased by some $10 \%$ from its calibrated level, indicating an increase in the effective rate of public investment, then all programmes improve (compare sections II and III in Table A2). For a constant level of $\delta$, an increase in $\lambda$ raises the productivity of the upcoming generations, leading to higher growth rates. Yet, alternative programs 'WITP', 'WTP', and 'HP' improve more significantly then the case with a lower $\lambda$ (see Table A1).

\section{$\alpha$ : capital income share}

If we test the model's sensitivity with respect to a higher level of $\alpha$, thus a higher level of capital income share, we observe that cuts in education spending under the 'PSP' would have less severe impact on economic growth. Furthermore, due to the 'relaxed' investment opportunities under alternative programmes, the stated dilemma between fiscal austerity and growth deepens (see Tables A1 and A2). 